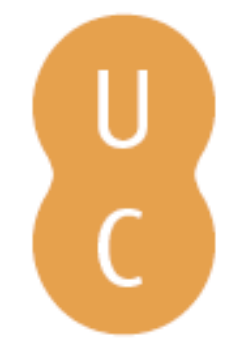

\title{
pommalina
}

\section{"Alimentar" o auto-da-fé: uma incursão pelos gastos do principal cerimonial da Inquisição portuguesa no século XVIII}

\author{
Autor(es): $\quad$ Lopes, Bruno \\ Publicado por: Imprensa da Universidade de Coimbra \\ URL \\ persistente: URI:http://hdl.handle.net/10316.2/45251 \\ DOI: $\quad$ DOI:https://doi.org/10.14195/978-989-26-1720-6_11 \\ Accessed : $\quad$ 26-Apr-2023 01:27:39
}

A navegação consulta e descarregamento dos títulos inseridos nas Bibliotecas Digitais UC Digitalis, UC Pombalina e UC Impactum, pressupõem a aceitação plena e sem reservas dos Termos e Condições de Uso destas Bibliotecas Digitais, disponíveis em https://digitalis.uc.pt/pt-pt/termos.

Conforme exposto nos referidos Termos e Condições de Uso, o descarregamento de títulos de acesso restrito requer uma licença válida de autorização devendo o utilizador aceder ao(s) documento(s) a partir de um endereço de IP da instituição detentora da supramencionada licença.

Ao utilizador é apenas permitido o descarregamento para uso pessoal, pelo que o emprego do(s) título(s) descarregado(s) para outro fim, designadamente comercial, carece de autorização do respetivo autor ou editor da obra.

Na medida em que todas as obras da UC Digitalis se encontram protegidas pelo Código do Direito de Autor e Direitos Conexos e demais legislação aplicável, toda a cópia, parcial ou total, deste documento, nos casos em que é legalmente admitida, deverá conter ou fazer-se acompanhar por este aviso.

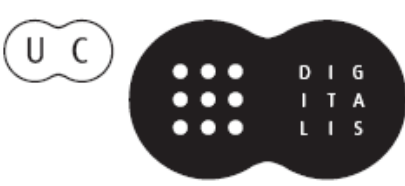


Carmen Soares

\section{Cilene da Silva Gomes Ribeiro}

\section{(coords.)}

MESAS

\section{ALIMENTAÇÃ O, SAÚDE \& CULTURA}

\section{IU LUO-BRASILEIRAS}

\section{VOLUME II}

IMPRENSA DA UNIVERSIDADE DE COIMBRA

COIMBRA UNIVERSITY PRESS

PUCPRESS 


\title{
“Alimentar" o AUTO-DA-FÉ: UMA INCURSÃo PELOS GASTOS DO PRINCIPAL CERIMONIAL DA INQUISIÇÃo PORTUGUESA NO SÉCULO XVIII ${ }^{1}$
}

\author{
("Feeding" the auto-da-fé: an incursion through \\ the expenses of the principal ceremonial of the \\ Portuguese Inquisition in the $18^{\text {th }}$ century)
}

\author{
Bruno Lopes \\ UNIVERSIDADE DE ÉVORA, \\ CIDEHUS - Universidade de ÉVORA, \\ CiTCEM - Universidade do Porto, \\ Bolseiro FCT (SFRH/BD/84I6I/20I2), \\ Doutorando do Programa Interuniversitário \\ de Doutoramento em História \\ BRUNO-LOPES85@HOTMAIL.COM
}

Resumo: O auto-da-fé, consumido como um espectáculo pelos coevos, era o expoente máximo da expressão do poder inquisitorial. Era durante a sua realização que a actividade do Santo Ofício se tornava pública. Após muitos meses - por vezes, até anos - em que o réu tinha estado encarcerado, finalmente, prestava-se contas, junto da população, para parafrasear Francisco Bethencourt. Quebrava-se, deste modo, o silêncio que era um dos pilares da existência do Tribunal da Fé. Neste trabalho, pretende-se analisar a estrutura dos gastos do auto-da-fé, o que permitirá contextualizar os custos com a alimentação (jantar da véspera ou almoço/jantar do dia da realização do cerimonial). Tentar-se-á identificar eventuais diferenças entre os quadros de ministros e oficiais - do ponto de vista dos alimentos consumidos. No fundo, questionar: que hierarquias podem ser identificadas a partir daqui? Haveria diferenças substanciais? Tratava-se de um momento que era partilhado por todos, ou eram separados: ministros para um lado, oficiais para o outro? Sabe-se que havia diferentes elementos de várias instituições envolvidas na realização do auto-da-fé, mas será que todos partilhavam a mesma refeição? Eram estas reservadas apenas aos membros da Inquisição? O que representava a realização do auto, no quadro global das despesas da instituição?

Palavras-Chave: Inquisição, auto-da-fé, finanças, alimentação, sociabilidades à mesa.

1 Trabalho desenvolvido no âmbito de: UID/HIS/00057/2013 (POCI-01-0145FEDER-007702), FCT/Portugal, COMPETE, FEDER, Portugal, 2020. Agradecem-se a revisão e os comentários ao texto à Prof. ${ }^{\text {a }}$ Doutora Fernanda Olival e ao Prof. Doutor José Damião Rodrigues. 
Abstract: The auto-da-fé had represented the public exhibition of power by the Portuguese Inquisition. It was during its execution that the activity of Holy Office was made public. It happened after many months - even years - in which the defendant had been imprisoned and finally the final product of their work was shown to the society, quoting Francisco Bethencourt. In this way it was broken the silence, that was one of the pillars of the Inquisition existence. In this work, we intend to analyse the structure of spending's on the auto-da-fé, what will allow us to contextualize the food costs (dinner of the day before or lunch/dinner of the day of the auto execution). We will try to identify the differences between the executive ministers and the officials of executive branch in what the foods consumed are concerned. In other words, what hierarchies can be identified from this point? Were there substantial differences? Was it a moment that was shared by all or were they separated: ministers to one side, officials to the other? That is, it is known that there were different elements from several institutions involved in the carrying out of the auto-de-fé, but will it be true that all of them shared the same meal? Were these meals reserved only to the members of Inquisition?

Keywords: Inquisition, auto-da-fé, finances, food, sociability at table.

Para quem segue de perto as alterações que a historiografia, dedicada ao Antigo Regime, tem sofrido nos últimos anos, depara-se com um forte investimento no que respeita aos estudos dedicados ao Santo Ofício ${ }^{2}$, quer seja no espaço português, no espanhol ou no italiano. Começam a abrir-se novos caminhos no sentido de compreender o enraizamento local, as ligações que esta instituição - poderosa, pode dizer-se - teve com os demais poderes que compunham a sociedade moderna, assim como as consequências da sua actividade.

Coevamente à existência dos tribunais inquisitoriais, construiu-se a ideia que o auto-da-fé era a expressão máxima do horror que o Santo Ofício impunha sobre a população ${ }^{3}$. O pensamento arbitrista pegaria nesta ideia para dar ao prelo trabalhos que iam contra a necessidade que os reinos tinham deste tipo de instituições. O século XIX, com o pensamento liberal, retomaria estes argumentos para exacerbar a luta contra o poder da Igreja e das suas instituições e vincular a necessidade da separação entre a Igreja e o Estado. Todo este trabalho acabou por cimentar a ideia que o auto correspondia à aplicação da pena capital - o que não correspondia à realidade - uma vez que no cerimonial se liam as sentenças; quando havia relaxados, eram entregues à

2 Citem-se apenas alguns exemplos: López-Salazar Codes 2011; Maifreda 2014; Marcocci, Paiva 2013. Mattos 2014. 
justiça secular, que executava a pena, fora do auto. Estes, não correspondiam à maioria das penas aplicadas pelo Santo Ofício ${ }^{4}$.

Este cerimonial era, sem dúvida, um elemento fundamental nas lógicas de existência do Tribunal da Fé. Quer no seu formato público, quer no privado, era o ritual onde os réus ouviam as suas sentenças e onde a Inquisição legitimava, perante os olhos da sociedade, o porquê da sua existência ${ }^{5}$.

O trabalho está estruturado em três eixos fundamentais, suportados por uma análise de cariz financeiro. Não interessará, tanto, estabelecer a análise do ponto de vista do cerimonial em si, como fez Francisco Bethencourt ${ }^{6}$, ou do significado social de que estes momentos se revestiam ${ }^{7}$. Do mesmo modo, não se prenderá a atenção num auto específico - de que há vários exemplos para a historiografia espanhola ${ }^{8}$ - ou como Isaías da Rosa Pereira fez, para aquele onde foi sentenciado o célebre padre Malagrida ${ }^{9}$.

Assim, o primeiro eixo de análise desdobra-se em dois aspectos: como e por quem eram financiados os autos-da-fé e qual o papel das suas despesas de realização no volume global dos gastos dos três tribunais inquisitoriais metropolitanos (Coimbra, Évora e Lisboa).

A historiografia, nomeadamente, com os trabalhos de António José Saraiva, tem feito querer parecer que o financiamento da Inquisição dependia, na sua maioria, do confisco de bens ${ }^{10}$. Esta ideia tem vindo a ser analisada com maior profundidade, percebendo-se que houve momentos onde a Inquisição foi instrumentalizada pelo poder régio para confiscar os bens de determinado indivíduo ${ }^{11}$; outros trabalhos sugerem que, em momentos de crise económica, a Inquisição aumentou a perseguição e o confisco de bens ${ }^{12}$. Começa a ser, todavia, ponto assente que o Tribunal não dependia financeiramente apenas dos bens que confiscava, mas possuía outros meios de sustentação, que passavam pelos bens da Coroa e da Igreja ${ }^{13}$.

Coloca-se, porém, a hipótese que, apesar do referido, em matéria de suporte de gastos com estes cerimoniais, era dos cofres dos Juízos do Fisco - entidades que coincidiam, territorialmente, com os tribunais do Santo Ofício - e que tinham a seu cargo a gestão dos bens sequestrados, e a ulterior venda em praça

Veja-se, por exemplo: Anderson 2012.

Bethencourt 2012: 154.

Bethencourt 1994: 195-257.

Barros Carollo 1999; Braga 2009; Maqueda Abreu 1986.

Águeda Méndez 2004; Arias Pardo, Fernández Carrasco 2009; Escudero Ríos 1983;

Fernández Carrasco 2005; García-Molina Riquelme 1994; Lahoz Finestres, Benedicto Gracia 2011.

Pereira 1982.

Saraiva 1956; Saraiva 1969.

Costa 2002.

Antunes, Silva 2012.

13 López-Salazar Codes 2011; Marcocci, Paiva 2013; Lopes 2014; Lopes 2016. 
pública, que saíam as verbas para pagamento das despesas de realização dos autos-da-fé. Gradualmente, estes organismos foram, também, desenvolvendo estratégias de acumulação de bens e de capital que lhes permitissem ter uma disponibilidade financeira constante. Não se deve esquecer que, embora os réditos auferidos com o sequestro, e posterior confisco de bens, tivessem como destino os cofres da Coroa, era o inquisidor-geral quem tinha o poder de dispor sobre o futuro a dar a estas verbas, num primeiro momento. Era às suas mãos que eram emitidas as provisões para as transições de réditos entre os Juízos do Fisco e os tribunais do Santo Ofício.

É fundamental esclarecer que este trabalho não se centra nos gastos relativos aos processados em cada auto. O processo-crime dava lugar a custas que eram suportadas pelo próprio, e pagas através dos Juízos do Fisco às Inquisições. Eram as primeiras entidades que geriam os réditos relativos aos presos, quer fosse em matéria de confisco, quer de gastos relativos a eles. As custas incluíam pagamentos a todos os agentes envolvidos nas diligências processuais dentro (ministros, notários...) e fora dos tribunais (comissários, notários e familiares do Santo Ofício).

Era também aos Juízos do Fisco que cabia a tarefa de subvencionar os gastos com os presos, que estavam divididos entre ricos (os que poderiam sustentar-se à sua custa, sem que fossem necessariamente pessoas com recursos financeiros elevados) e pobres (os que não o conseguiam). Só, pontualmente, estas despesas eram custeadas pelos tribunais inquisitoriais.

Após estas questões iniciais - que justificam boa parte da importância e novidade que este estudo pode trazer - tratar-se-á do segundo eixo de análise: a estrutura dos gastos do auto-da-fé. Para este efeito, irá propor-se uma grelha classificativa dos valores despendidos.

Do desenho feito da estrutura das despesas com a realização dos autos, partir-se-á para o terceiro vector analítico: o estudo dos gastos em alimentação. Desde aqui, poder-se-ão identificar as práticas de sociabilidade prévias e durante aqueles cerimoniais, permitindo saber, por exemplo, de que maneira a hierarquia do Santo Ofício - dividida entre ministros e oficiais, que eram coadjuvados pelas redes de agentes locais - se traduzia nos rituais que envolviam a partilha de refeições. Por outro lado, permitirá identificar outros indivíduos - externos à instituição - que também partilhavam os espaços inquisitoriais, nos dias que antecediam a realização do auto e, pelas funções, que lhes eram atribuídas, eram alimentados pelo Tribunal.

Em síntese, através das fontes financeiras do Santo Ofício poder-se-á concluir qual a importância dos gastos com os autos-da-fé nas contas globais da instituição. Não se deve esquecer que estes cerimoniais revestiam-se de poder simbólico e ocupavam um lugar central na vida da Inquisição, a par, por exemplo, da festa de São Pedro Mártir, padroeiro da Inquisição. 
A tónica fundamental, deste trabalho, assenta na partilha de refeições e de que modo se traduziam em diversos momentos de sociabilidade e reflectiam, através dos alimentos consumidos, as hierarquias inquisitoriais.

As fontes utilizadas são os livros da casa (anuais para cada tribunal), nos quais os tesoureiros da Inquisição registavam as receitas e as despesas. Tratava-se da gestão da casa, ou seja, dos edifícios e, nalguns dos anos, incluem os róis de gastos com os autos-da-fé. Utilizaram-se, também, os relatórios de contas enviados anualmente pelos tribunais para o Conselho Geral, em Lisboa; perderam-se estes documentos para Coimbra. De forma secundária, fizeram-se, ainda, algumas sondagens nos maços de documentação avulsa da Inquisição de Lisboa. Estes últimos para tratar, fundamentalmente, os valores globais de receita e despesa.

Ressalve-se que, há livros classificados ${ }^{14}$ para todos os tribunais como despesas dos autos-da-fé que, salvo raras excepções, não respeitam à análise que se pretende desenvolver neste trabalho. São, afinal, cadernos resultantes da junção das listas pagas aos agentes envolvidas nos processos-crime e que constituíam as custas, a serem pagas pelos sentenciados. De resto, o regimento da Inquisição de 1640 não previa a sua existência ${ }^{15}$.

Do ponto de vista metodológico, escolheu-se uma análise estatística, com recurso a folhas de Excel, a fim de criar classes analíticas. Estes dados foram, depois contextualizados, com recurso a fontes qualitativas, com o objectivo de dar contexto aos números.

O recorte cronológico é mediado pelos anos de 1700 e 1760, escolha que se deveu, principalmente, à disponibilidade de fontes. Para além disso, o critério teve a ver com o facto de, em 1760, se ter celebrado, em Évora, o último auto-da-fé público deste tribunal distrital. Escolheu-se, assim um período cronológico, onde os três tribunais inquisitoriais procediam à realização destes cerimoniais, ainda que os de Coimbra e Lisboa tenham tido mais alguns nas décadas seguintes.

14 Farinha 1990 - Coimbra: 242; Évora: 286; Lisboa: 187-188.

15 Liv. I, Tít. VIII, § 2. (Publ. Franco, Assunção 2004). 


\section{CONTABilidade inQUisitorial E AUTOS-DA-FÉ: UMA APROXIMAÇÃo AO TEMA}

Nos dias que antecediam o auto-da-fé, ou nos imediatamente posteriores, o inquisidor-geral emitia as provisões ${ }^{16}$ que ordenavam ao tesoureiro/ depositário do Juízo do Fisco, que pagasse aos tribunais inquisitoriais as despesas referentes ao cerimonial. Era assim feito para todas as mesas distritais. Tendencialmente, as ordens de pagamento incluíam a remuneração das custas dos processos aos agentes implicados, como se referiu, assim como as propinas aos diferentes membros dos tribunais e aos do Conselho Geral - entidade máxima na hierarquia inquisitorial - e também os gastos de realização do auto. No caso de Lisboa, normalmente, os valores eram entregues pelo agente do Fisco ao tribunal e era, este último, que os entregava aos membros e oficiais do Conselho. Este sistema de pagamento resultava do trabalho prévio do tesoureiro, que tinha a tarefa - definida em regimento - de elaborar o rol das coisas necessárias à realização do auto, alguns dias antes da sua celebração. Uma vez feito, deveria apresentá-lo na mesa do tribunal para ser aprovado pelos ministros. Deveria proceder à aquisição de tudo o que fosse necessário com a máxima cautela, para evitar que se espalhasse a notícia, antes de tempo, que se iria realizar um auto-da-fé ${ }^{17}$.

Sendo a realização deste cerimonial um momento pontual na actividade inquisitorial, através do qual se mostrava à sociedade o produto da sua actividade, verifica-se que, ao longo do século XVIII, a tendência foi para que estes momentos passassem a ser circunscritos aos interiores dos tribunais da Inquisição - eram por isso chamados de "autos da sala" ou "privados". $\mathrm{Na}$ segunda metade da centúria, concretamente, a partir dos anos de 1760, verifica-se uma tendência para desaparecerem os públicos, o que se associa à mudança de valores que por esta altura se fazia sentir ${ }^{18}$ e por todas as transformações políticas a que o Santo Ofício foi sujeito, por parte da Coroa.

16 Veja-se um exemplo de Coimbra: "Carregam-se aqui sobre o licenciado Manuel Moniz um 1:175.131 réis que recebeu de Manuel Gomes Heirigo depositário dos bens do fisco desta cidade por virtude de uma provisão de Sua Eminência para pagamento das custas do auto-da-fé de 25 de Maio de 1727 [...]". ANTT [Arquivo Nacional da Torre do Tombo], Inq. Coimbra 435: 14.

17 Regimento de 1640: Liv. I, Tít. VIII, § 11. (Publ. Franco, Assunção 2004).

18 "[...] Acabaram por desaparecer da vista da população. Em Évora o derradeiro foi em 1760, em Lisboa no ano de 1778, e, por fim, em Coimbra em 1781, na sala da Inquisição. Isso sucedeu a par com as alterações do quadro geral de valores que, sobretudo por inspiração das correntes iluministas e secularizadoras, estavam a torná-los inaceitáveis, mas também devido a contingências de outra natureza, explicitadas pelos inquisidores de Lisboa, em 1767. Não havia réus suficientes para os organizar e a cerimónia tinha custos financeiros elevados que assim se evitavam" (Marcocci, Paiva 2013: 263). 


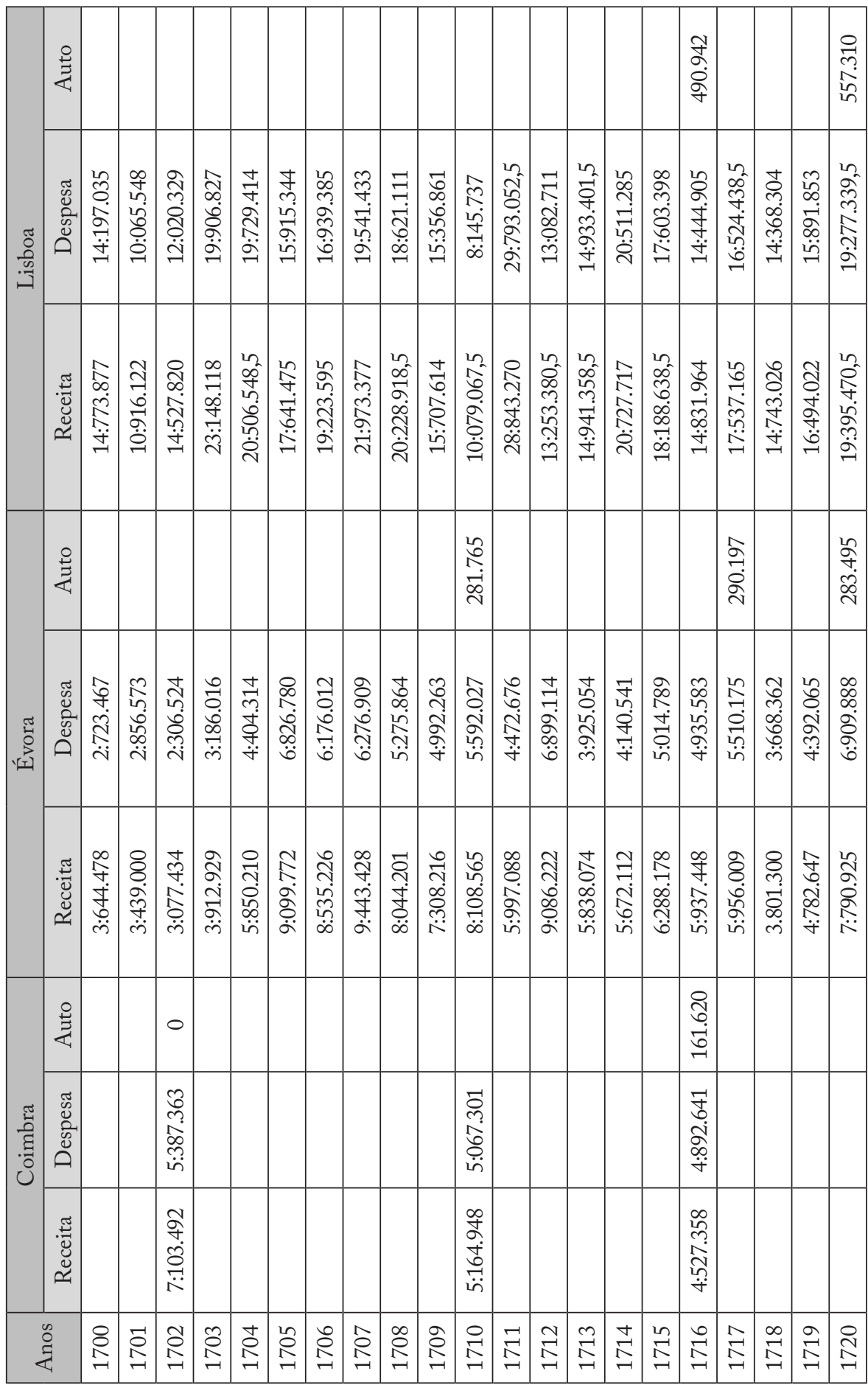




\begin{tabular}{|c|c|c|c|c|c|c|c|c|c|c|c|c|c|c|c|c|c|c|}
\hline 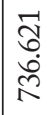 & 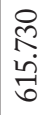 & & 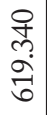 & 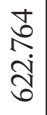 & & & & 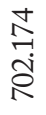 & & $\begin{array}{l}\stackrel{R}{0} \\
0 \\
\text { N }\end{array}$ & & 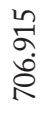 & & & & 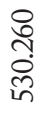 & & \\
\hline 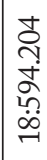 & $\begin{array}{l}0 \\
\infty \\
1 \\
0 \\
0 \\
0 \\
\stackrel{0}{0} \\
\stackrel{-}{-}\end{array}$ & $\begin{array}{l}12 \\
8 \\
+ \\
\dot{0} \\
0 \\
\dot{0} \\
\dot{n}\end{array}$ & 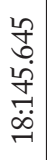 & 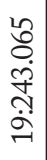 & 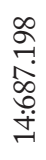 & 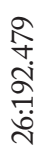 & 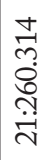 & 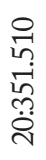 & 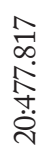 & 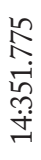 & 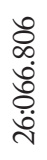 & 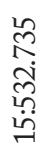 & $\begin{array}{l}8 \\
\infty \\
10 \\
8 \\
8 \\
\stackrel{+}{0} \\
\stackrel{8}{0}\end{array}$ & 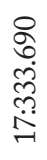 & 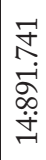 & 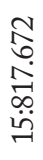 & 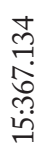 & 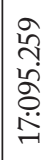 \\
\hline
\end{tabular}

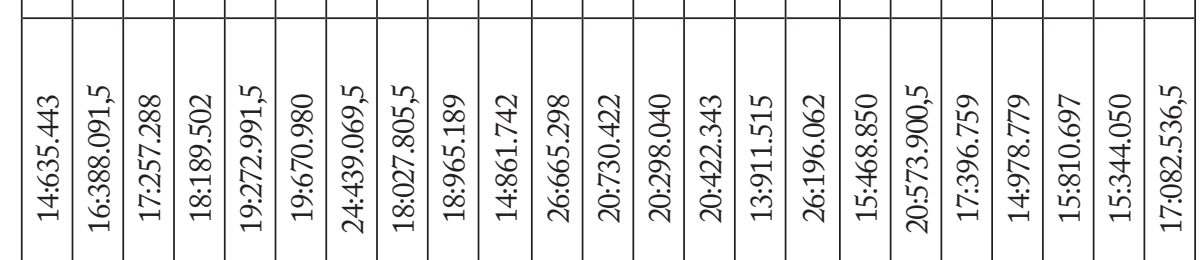

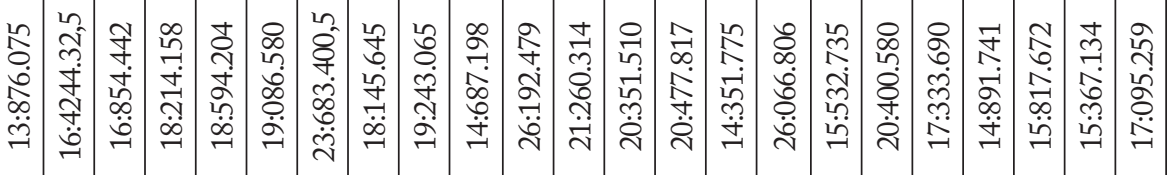

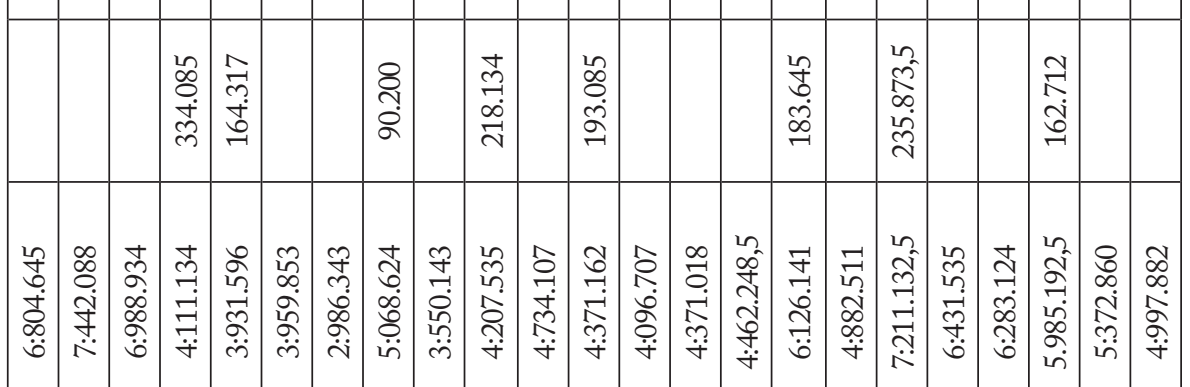

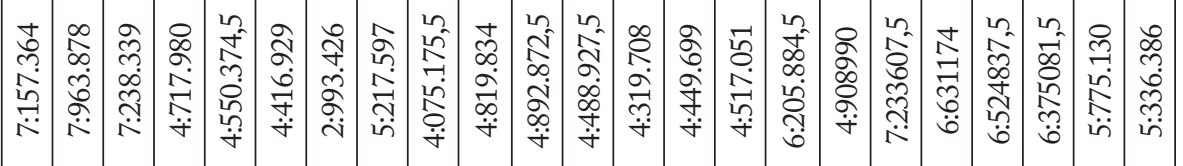

\begin{tabular}{|c|c|c|c|c|c|c|c|c|c|c|c|c|c|c|c|c|c|c|c|c|c|c|}
\hline & & & & & $\begin{array}{l}8 \\
\swarrow \\
2 \\
\end{array}$ & $\begin{array}{c}8 \\
\delta \\
\text {. } \\
\infty \\
-\end{array}$ & & $\begin{array}{l}\stackrel{\rho}{+} \\
\stackrel{a}{\sigma} \\
-1\end{array}$ & $\begin{array}{l}\stackrel{尺}{0} \\
\stackrel{0}{ } \\
\stackrel{\leftrightarrow}{-}\end{array}$ & & 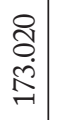 & & & & & $\begin{array}{l}\stackrel{+}{0} \\
\text { m } \\
\dot{b} \\
\stackrel{-}{*}\end{array}$ & & & & & $\begin{array}{l}\text { 모․ } \\
\text { ì } \\
\text { ñ }\end{array}$ & \\
\hline & & & $\begin{array}{l}\hat{\sigma} \\
\infty \\
0 \\
\stackrel{0}{0} \\
\stackrel{\forall}{*}\end{array}$ & & 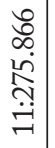 & 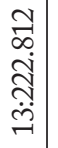 & & 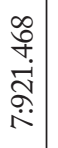 & 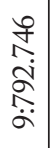 & & 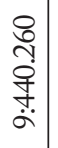 & & & 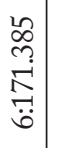 & $\begin{array}{l}1 \\
\infty \\
0 \\
\stackrel{0}{0} \\
\stackrel{+}{0}\end{array}$ & $\begin{array}{l}\infty \\
\delta \\
\stackrel{-}{\alpha} \\
\grave{1} \\
\dot{\infty}\end{array}$ & & & & 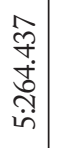 & 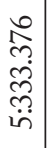 & \\
\hline & & & 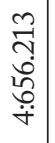 & & 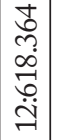 & 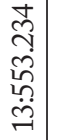 & & 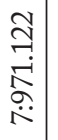 & $\begin{array}{l}\tilde{\curvearrowright} \\
\hat{i} \\
\alpha \\
\alpha\end{array}$ & & $\begin{array}{l}\vec{n} \\
\stackrel{\sim}{n} \\
\stackrel{n}{N} \\
\stackrel{\sigma}{\sigma}\end{array}$ & & & 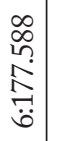 & 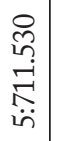 & 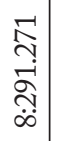 & & & & 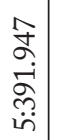 & 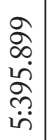 & \\
\hline$\underset{\stackrel{I}{I}}{\vec{I}}$ & $\underset{I}{\mathbb{N}}$ & $\stackrel{\tilde{N}}{\underset{\sim}{-}}$ & $\underset{\sim}{\stackrel{\mathbb{N}}{ \pm}}$ & $\underset{\sim}{\stackrel{N}{N}}$ & 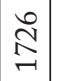 & $\stackrel{\widehat{N}}{\sim}$ & 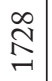 & 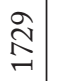 & 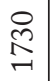 & $\overrightarrow{\tilde{n}}$ & $\stackrel{\widetilde{\Omega}}{ح}$ & 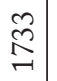 & 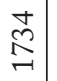 & $\stackrel{2}{\stackrel{2}{\sigma}}$ & 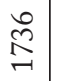 & న̂ & $\begin{array}{l}\infty \\
\stackrel{\sim}{\sim}\end{array}$ & હે & 옴 & 胥 & 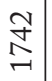 & $\underset{\stackrel{\overbrace{}}{+}}{\stackrel{\sim}{\sim}}$ \\
\hline
\end{tabular}




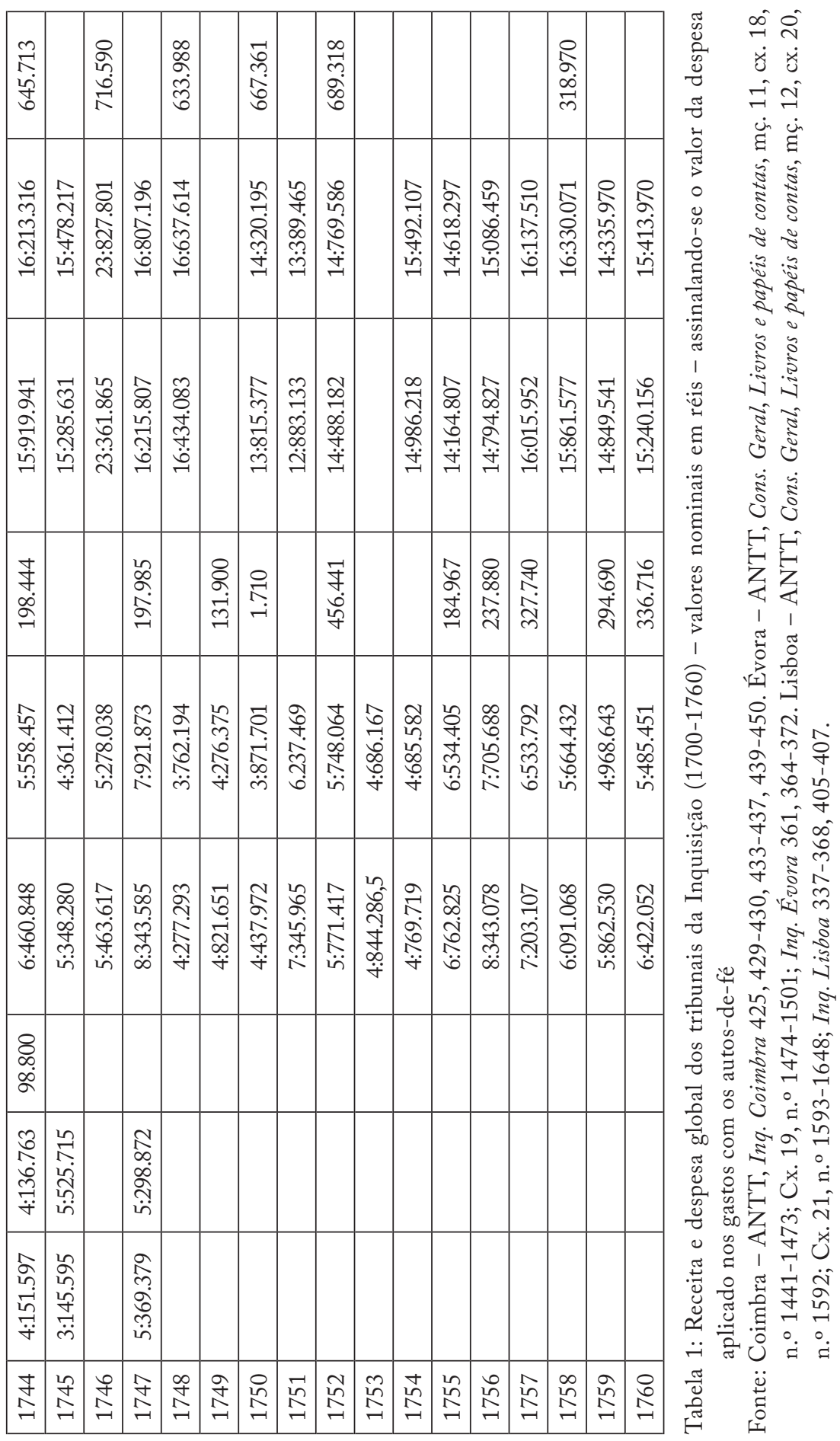


$\mathrm{Na}$ Tabela 1 representaram-se as receitas e as despesas dos diferentes tribunais da Inquisição, destacando-se os gastos realizados com os autos-da-fé. Por vezes, as fontes não são explícitas em distinguir se se tratava de cerimoniais públicos ou privados. Para além disso, em muitos casos, não há informação acerca da data da sua realização, o que torna difícil o cruzamento de dados. Poderia, ainda, acontecer que parte das despesas dos autos privados fossem pagas em conjunto com as dos públicos, uma vez que seriam de menor monta - assim aconteceu, por exemplo, com as despesas da cera dos autos privados de Coimbra de $1728 \mathrm{e}$ de 1737 , que foram pagas, em simultâneo, ao cerieiro com a do auto público ${ }^{19}$.

\begin{tabular}{|c|c|c|c|}
\hline Categorias & Média & Mediana & Moda \\
\hline \multicolumn{5}{|c|}{ Coimbra } \\
\hline Receita & $6: 985.142$ & $5: 711.530$ & - \\
\hline Despesa global & $6: 896.225$ & $5: 436.867$ & - \\
\hline Despesas do auto & 161.708 & 169.140 & 173.020 \\
\hline \multicolumn{4}{|c|}{ Évora } \\
\hline Receita & $5: 885.131$ & $5: 838.074$ & - \\
\hline Despesa global & $5: 117.069$ & $4: 992.263$ & - \\
\hline Despesas do auto & 228.856 & 218.134 & - \\
\hline \multicolumn{5}{|c|}{ Lisboa } \\
\hline Receita & $17: 433.678$ & $16: 388.092$ & - \\
\hline Despesa global & $17: 113.156$ & $16: 330.071$ & - \\
\hline Despesas do auto & 626.941 & 639.850 & \\
\hline
\end{tabular}

Tabela 2: Cálculos médios das receitas e despesas dos tribunais da Inquisição (1700-1760)

- valores nominais (réis)

Fonte: $\mathrm{O}$ autor, a partir das fontes referidas na Tabela 1

Com a análise da Tabela 2, verifica-se, logo à partida, que a Inquisição portuguesa setecentista era uma instituição auto-suficiente, financeiramente, uma vez que os valores médios de receitas são superiores aos das despesas, pese embora algum jogo por parte dos tesoureiros para fazer com que a receita coincidisse com a despesa ${ }^{20}$. Constata-se, também, que o tribunal com maior volume de receita/despesa era o de Lisboa. Isto não era fruto do acaso, uma vez que era a mesa mais importante, por se localizar na corte, e por ter a seu cargo boa parte dos gastos do Conselho $\mathrm{Geral}^{21}$, que incluíam, por exemplo os salários dos deputados. Era assim desde $1579^{22}$. Não é, por isso, de estranhar que os autos-da-fé tivessem maiores gastos aqui. Eram, certamente, mais faustosos e

\footnotetext{
19 ANTT, Inq. Lisboa, mç. 6, n.o 24.

20 Lopes 2014

21 Lopes 2016.

22 ANTT, Inq. Lisboa 330: 242.
} 
nos quais participava um número maior de ministros/oficiais do tribunal ${ }^{23}$ (sujeitos ao pagamento de mais propinas), onde mais presos ouviriam as suas sentenças e era o local onde a Inquisição zelava por maior afirmação do seu poder. Era a capital do reino.

Atentando-se nos valores médios dos gastos com os cerimoniais, em diálogo com o valor global das despesas, verifica-se que era em Évora que a realização dos autos significava um maior esforço financeiro (4,5\%), pese embora tivesse sido aqui que se realizaram menos autos públicos no século XVIII ${ }^{24}$, o que, consequentemente, originava um número menor de sentenciados, quase metade daqueles que se registam para os outros tribunais, no período de 1675 a $1767^{25}$. Seguia-se Lisboa $(3,4 \%)$ e, por fim, Coimbra (com 2,3\%).

Com estes dados, corrobora-se a hipótese, colocadas por Giuseppe Marcocci e José Pedro Paiva, para a redução do número de autos-da-fé públicos, assente na ideia de que eles representavam custos financeiros elevados. Neste particular não se deve obliterar, todavia, a mudança de valores sociais e a perda de sentido $\mathrm{da}$ actividade inquisitorial repressiva e controladora de comportamentos e as alterações institucionais, que o Tribunal sofreu a partir dos anos de $1760^{26}$.

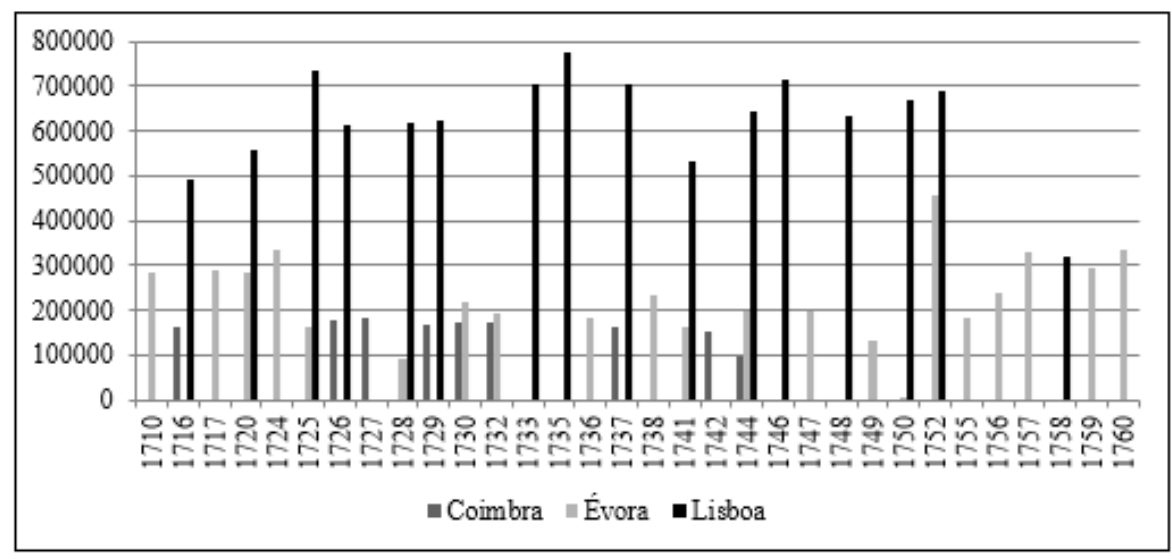

Gráfico 1: Custos dos autos-da-fé dos tribunais da Inquisição (1700-1760) - valores nominais em réis. Assinalaram-se apenas os anos para os quais há despesas de realização dos autos

Fonte: ANTT, Cons. Geral, Livros e papéis de contas, mç. 11, cx. 18, n. ${ }^{\circ}$ 1441-1473; Cx. 19, n. ${ }^{\circ}$ 1474-1501, mç. 12, cx. 20, n.o 1592; Cx. 21, n. ${ }^{\circ}$ 1593-1648; Inq. Coimbra 425, 429-430, 433-437, 439-450; Inq. Évora 361, 364-372; Inq. Lisboa 337-368, 405-407.

\footnotetext{
23 Bethencourt 1994.

24 Marcocci, Paiva 2013: 263.

25 Bethencourt 1994: 275.

26 Bethencourt 1987.
} 
Com a análise dos custos efectivos da realização dos autos-da-fé (Gráfico 1) confirma-se o já explicitado: Lisboa era o tribunal onde eram mais custosos. Se se tomar o ano de 1744 como referencial, verifica-se aquela afirmação, uma vez que é o único para o qual se dispõe de dados para os três tribunais (Gráfico 1). Mas nem sempre assim era, pois, após 1755 , com a cidade devastada, foi necessário reerguer os edifícios. A Inquisição não foi excepção e, por isso, só em 1758, se realizou novo auto. É curioso notar, contudo, que terá sido um cerimonial mais modesto, a julgar pelo valor gasto (318.970 réis) - que representava $2 \%$ de todas as despesas (Tabela 1 ) - rédito próximo daqueles que seriam usuais nos demais tribunais; eram consequências do terramoto.

Em 1767, a mesma mesa queixava-se de que os réus não eram suficientes para se proceder à realização de um auto, pelo que deveriam ser despachados, para não estarem a representar gastos extraordinários para o Juízo do Fisco ${ }^{27}$, pois sendo a maioria deles pobres, era esta a entidade que deveria zelar pela sua manutenção nos cárceres.

Pode, assim, concluir-se que embora o auto-da-fé fosse o cerimonial mais importante nas lógicas da actividade inquisitorial, não representava um esforço financeiro excessivo para os tribunais. Era em Lisboa, capital e sede do tribunal mais importante e do Conselho Geral, que as verbas aplicadas na sua realização eram de maior monta. Porém, se se atender à percentagem destes gastos no volume das despesas, conclui-se que era em Évora que os autos representavam um maior esforço financeiro.

A sua realização estaria, ainda, sujeita à disponibilidade financeira dos Juízos do Fisco, uma vez que, ainda que sob a alçada do inquisidor-geral, cabia-lhes o pagamento de todas as despesas do auto. Há que salientar que, embora se tenha considerado a instituição como sendo auto-suficiente financeiramente, a Inquisição não tinha à disposição capital próprio que permitisse adiantar o pagamento destas despesas.

\section{O AUTO-DA-FÉ EM NÚMEROS}

Visto o papel que ocupavam os autos-da-fé nos gastos anuais de cada um dos tribunais do Santo Ofício, interessará agora deslocar o inquérito para o desenho da sua composição. Como se referiu, cabia aos Juízos do Fisco o pagamento aos tribunais dos réditos necessários a todos os gastos. Quais eram eles?

A amostra utilizada - para a construção das Tabelas 3 a 5 - respeita às listagens dos gastos de realização dos autos-da-fé. Ressalve-se que, para Coimbra, estes valores parecem estar subavaliados, ou seja, embora fossem elaboradas as

\footnotetext{
$27 \quad$ ANTT, Inq. Lisboa 158: 231.
} 
listas de despesas efectuadas pelo auto, estas parecem não incluir todos os valores despendidos. Atendendo-se a estes dados, verifica-se que há anos nos quais estes róis eram mais detalhados (com mais categorias assinaladas) e outros nos quais os montantes principais assinalados eram referentes a grandes categorias, como propinas e mercês, alimentação, realização do auto e indivíduos externos ao Santo Ofício. Não se sabe, contudo, em que momento se pagavam as despesas não incluídas nestas listas. Através da comparação entre os róis dos outros tribunais e os de Coimbra, mais pormenorizados, conclui-se que os deste último tribunal não cobrem a totalidade das despesas realizadas. $\mathrm{O}$ ano de 1744 pode servir de exemplo, uma vez que se pagaram apenas as propinas e mercês ${ }^{28}$.

Assim, para classificar estes valores, propõe-se a seguinte grelha classificativa:

- Alimentação: incluíram-se todos os gastos em alimentos para os oficiais dos tribunais, mas também os que eram despendidos com agentes externos (eclesiásticos, impressores, mariolas, etc.).

- Cerieiro: róis de cera necessária para os autos, para os réus e para a iluminação dos espaços.

- Correios: gastos com transporte de correspondência.

- Imprensa: inclui os gastos com a impressão das listas do auto, e aquisição de materiais, como papel, para além do trabalho dos impressores.

- Individuos externos ao SO (Santo Ofício): incluíram-se os gastos com gente externa aos tribunais, como eclesiásticos ou os ministros das execuções das penas.

- Outros: incluíram-se dados não discriminados (só se utilizou uma vez).

- Pintores: despesas com elaboração de retratos dos réus defuntos/ ausentes, com estátuas e pinturas nos sambenitos.

- Presos: tudo o que respeitava aos réus, como tecidos e elaboração dos sambenitos, o transporte de bens pessoais, a leitura das sentenças.

- Propinas e mercês: pagamentos feitos aos oficiais do Santo Ofício pela ocasião do auto. Era comum dar-se propina para o jantar do auto e a tocha.

- Realização do auto: respeita a gastos mais miúdos, de pequenas tarefas, transporte de materiais, azeite para iluminação, etc.

Uma palavra para referir que, nestes róis de despesas, uma das ausências notadas é relativa à construção dos cadafalsos para os cerimoniais. É ainda de supor que despesas específicas com a realização do auto ou com a aplicação de determinadas penas saíssem, também, dos cofres dos Juízos do Fisco. Para a cronologia em apreço não foram identificados gastos com os cadafalsos, por

\footnotetext{
28 ANTT, Inq. Coimbra 445.
} 
exemplo. Coloca-se esta hipótese por uma ordem de pagamento feita pelo juiz do Fisco de Coimbra, onde se ordena que se pague ao meirinho da cidade a despesa com as cordas para "açoitar cinco pessoas que foram penitenciadas e saíram no auto público da fé que se celebrou no real Convento de Santa Cruz em o dia 8 de Julho de 1742"29.

Com base nesta categorização, é possível constatar que a principal dizia respeito às propinas e mercês. As primeiras eram pagas a todos os ministros e oficiais do corpus inquisitorial e aos membros do Conselho Geral (às mãos de Lisboa). As mercês eram pagas a alguns dos oficiais, como aos guardas que assistiam ao tormento dos réus e aos médicos/cirurgiões, pelo mesmo motivo, tal como aparece designado na documentação. Não é exactamente uma surpresa esta conclusão, uma vez que, num estudo ainda preliminar sobre as despesas globais da mesa de Évora, verifica-se que as verbas aplicadas aos pagamentos de salários e demais emolumentos ocupavam uma fatia substancial da estrutura dos gastos ${ }^{30}$.

\begin{tabular}{|c|c|c|c|c|c|c|c|c|c|c|c|}
\hline 竞 & 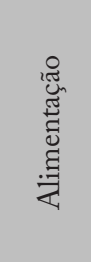 & Ů & 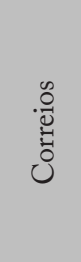 & 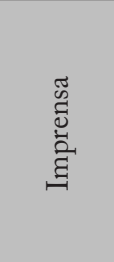 & 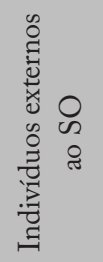 & $\overbrace{0}^{\infty}$ & 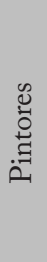 & 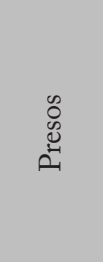 & 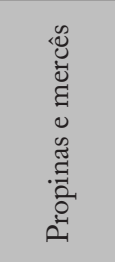 & 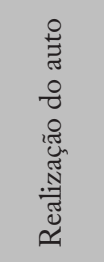 & 舁 \\
\hline 1716 & 26.000 & & & & 14.000 & & & & 90.900 & 30.720 & 161.620 \\
\hline 1726 & 6.000 & & 6.400 & & 14.560 & & & & 117.700 & 35.240 & 179.900 \\
\hline 1727 & 41.000 & & & & 20.560 & & & & 120.800 & 240 & 182.600 \\
\hline 1728 & 45.500 & 54.160 & & 51.920 & 23.200 & & & 55.300 & 139.300 & 6.120 & 375.500 \\
\hline 1729 & 41.000 & & & & 25.600 & & & & 102.300 & 240 & 169.140 \\
\hline 1730 & 41.000 & & & & 18.240 & & & & 113.300 & 480 & 173.020 \\
\hline 1732 & 41.000 & & & & 13.600 & & & & 117.700 & 720 & 173.020 \\
\hline 1737 & 41.000 & & & & 16.000 & & & & 107.100 & 240 & 164.340 \\
\hline 1742 & 41.000 & & & & 16.000 & & & & 95.700 & 240 & 152.940 \\
\hline 1744 & & & & & & & & & 98.800 & & 98.800 \\
\hline 1749 & 47.060 & 33.712 & & 107.280 & 13.600 & & & 45.605 & 483.200 & 240 & 730.697 \\
\hline 1751 & 41.000 & & & & 11.200 & & & & 110.700 & 240 & 163.140 \\
\hline 1751 & 41.000 & 32.570 & & 96.680 & 11.200 & & & 60.795 & 496.700 & 240 & 739.185 \\
\hline 1755 & 41.000 & & & & 14.400 & & & & 91.700 & 240 & 147.340 \\
\hline
\end{tabular}

Tabela 3: Estrutura dos gastos do auto-da-fé do Tribunal de Coimbra (1700-1760) - valores nominais (réis)

Fonte: ANTT, Inq. Coimbra 490, 434-437, 439, 442, 444-445, 447, 448; Inq. Lisboa, mç. 6, n. ${ }^{\circ} 24$.

\footnotetext{
${ }^{29}$ ANTT, Inq. Coimbra, mç. 65, n.o 1.

30 Lopes 2014.
} 


\begin{tabular}{|c|c|c|c|c|c|c|c|c|c|c|c|}
\hline$\stackrel{\infty}{\stackrel{1}{4}}$ & 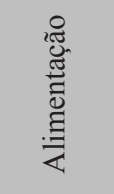 & $\cdot \frac{0}{0}$ & $\frac{\mathscr{0}}{\stackrel{0}{0}}$ & 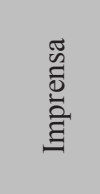 & 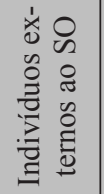 & 总 & 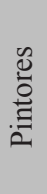 & $\begin{array}{l}0 \\
0 \\
0 \\
0 \\
0\end{array}$ & 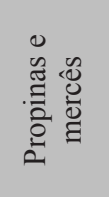 & 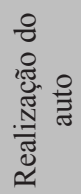 & 舁 \\
\hline 1710 & 167.725 & & & 15.400 & 12.000 & & & 1.400 & 82.000 & 3.240 & 281.765 \\
\hline 1724 & 225.645 & & 11.220 & 25.000 & 6.000 & & & & 58.200 & 8.020 & 334.085 \\
\hline 1725 & 36.250 & 1.507 & 15.110 & 38.050 & 4.000 & & & & 69.400 & & 164.317 \\
\hline 1744 & 44.134 & 1.650 & 16.920 & 40.540 & 8.000 & & & 20.000 & 66.000 & 1.200 & 198.444 \\
\hline 1752 & 50.391 & & 16.020 & 40.900 & 12.000 & & & 20.000 & 323.000 & 6.130 & 456.441 \\
\hline
\end{tabular}

Tabela 4: Estrutura dos gastos do auto-da-fé do Tribunal de Évora (1700-1760) - valores nominais (réis) Fonte: ANTT, Inq. Évora 365, 368-369, 373, 375.

Outras duas categorias também se destacam: a alimentação e a imprensa. Esta última, como referido, incluía ainda os gastos com o papel e todo o trabalho de impressão dos materiais necessários ao auto-da-fé (editais, listas de réus, folhas de abjuração, etc.). A Inquisição não dispunha de um impressor próprio, pelo que recorria a agentes externos.

Se estas três áreas eram comuns, aos tribunais em análise, não se pode dizer que as mesas seguissem um modelo contabilístico único, uma vez que parece não haver limites às despesas em cada uma das categorias. Estes limites existiam, por exemplo, com as obras: 20.000 réis/ano era o valor máximo que cada um podia gastar. Ultrapassando-se, era indispensável uma autorização do Conselho Geral ${ }^{31}$.

$\mathrm{Na}$ categoria da alimentação, constata-se que ocupava uma fatia maior nos gastos no tribunal de Évora, mas em todos era um item importante. Ainda assim, parece ter havido alguma redução, no decorrer do tempo, nestes gastos.

Refira-se que os ministros e oficiais recebiam a propina para o jantar, contudo, ambos realizavam refeições na véspera do auto e os ministros no cadafalso do cerimonial. Havia ali um espaço destinado a comida e refrescos, que seriam degustados no decorrer do $\mathrm{dia}^{32}$, uma vez que o auto podia tardar muitas horas, caso houvesse muitos réus. Seria assim desde o já longínquo século XVI, pois uma carta de Filipe II, em Abril de 1582, dirigida ao seu sobrinho, o duque de Alba, referia que estivera a assistir ao auto-da-fé das oito da manhã até à uma, indo, depois de concluídos os processos dos relaxados à justiça secular, comer ${ }^{33}$.

31 Consulta da Inquisição de Lisboa de 10 de Junho de 1721: "Nos corredores desta Inquisição, e partes circunvizinhas aos mesmos chove, e faz grande dano nos forros, a água que se comunica dos telhados, e mandando nós ver estes pelo mestre pedreiro, nos diz que importará o conserto de que necessitam, em quarenta mil réis, de que damos conta a Vossa Eminência pedindo licença para mandarmos fazer o dito conserto". ANTT, Inq. Lisboa 154: 569; 587.

32 Bethencourt 2000: 126. Marcocci, Paiva 2013: 273.

33 Megiani 2011:218. 


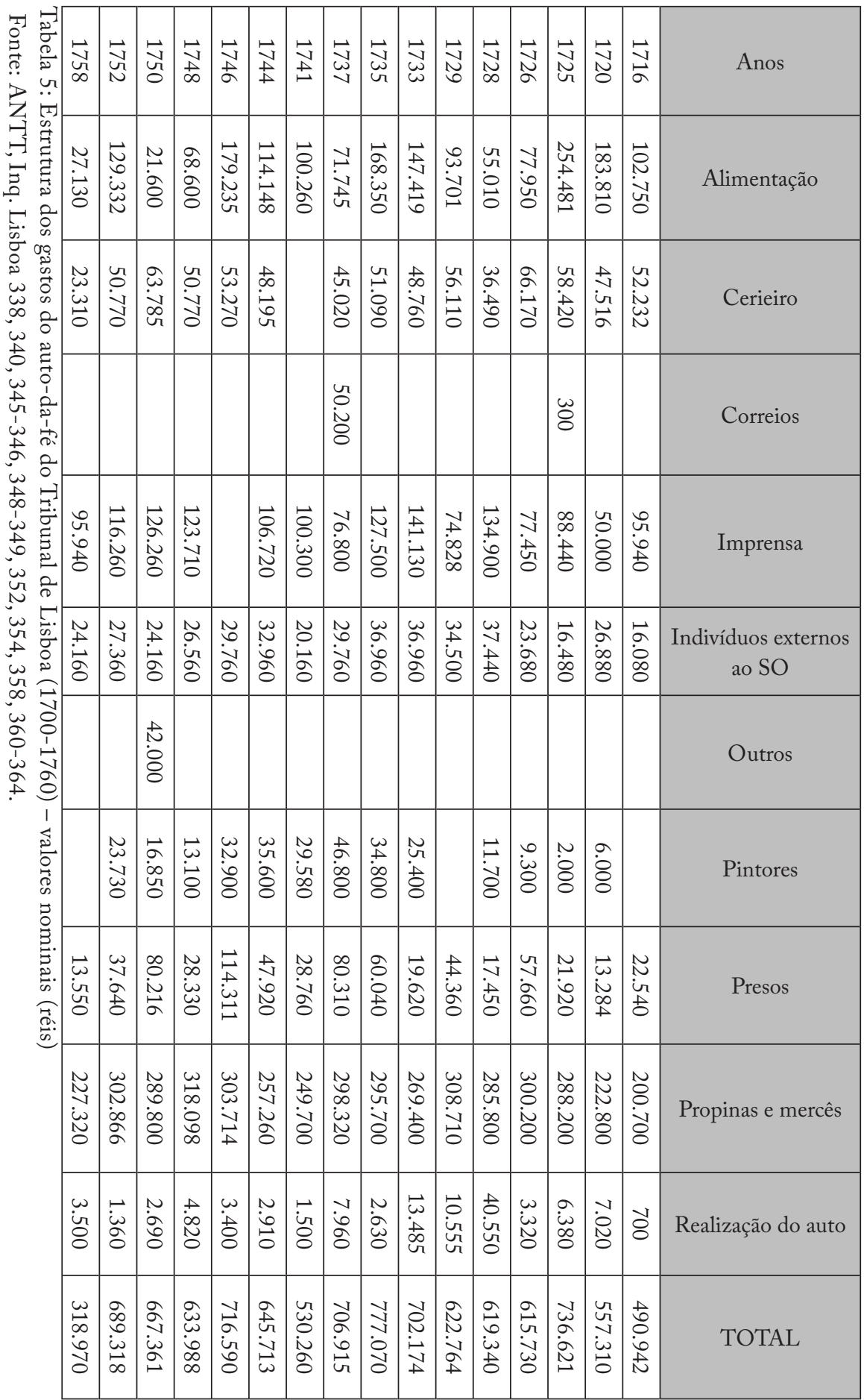


Ainda na classe de gastos com alimentação incluiu-se apenas o que respeita, efectivamente, a alimentos e não com as propinas referidas (as do jantar). Estes alimentos eram consumidos pelos ministros e oficiais, mas também pelos réus (sobretudo em Lisboa, dos anos de 1740/50 em diante). Somaram-se, também, os almoços, jantares e ceias dos impressores que se deslocavam com a sua maquinaria para os tribunais, assim como dos guardas, que trabalhavam cerca de quinze dias na preparação do auto, e por isso tinham de ser alimentados.

Também os eclesiásticos, chamados pelo Santo Ofício para ajudarem no cerimonial, tinham direito a refeições: em Lisboa eram, por vezes os padres da Companhia de Jesus, ou os do Hospital (referidos apenas assim; seriam os do Hospital de Todos-os-Santos) ${ }^{34}$. Muitas vezes não há menção da sua origem, apenas que ajudaram na absolvição dos réus e que leram as sentenças. Em Coimbra, eram os clérigos de Santa Justa ${ }^{35}$ e, em Évora, não se conhece a sua proveniência, mas, no século XVII, seriam os da Companhia de Jesus ${ }^{36}$.

Parece, ainda, verificar-se uma tendência para uma redução da verba aplicada em alimentação, a partir dos meados do século XVIII, sem que se conheçam as causas para isso. Uma tentativa de redução dos gastos com alimentação?

Em suma, as categorias da alimentação, das propinas e das despesas com a imprensa eram as principais no que respeita aos gastos dos autos-da-fé. Não se deve estranhar que a relativa aos presos não esteja entre elas, porque incluíram-se apenas os gastos com sambenitos, a leitura das sentenças e alguns gastos de pequena monta. Parte das despesas, com os réus, estão diluídas nas demais classes, como no auto de Lisboa, de 1752, em que no item "de comedoria aos presos que saíram no auto e dias que estiveram na penitência se pagou 50.102 réis" ${ }^{37}$, valor que se encontra somado na categoria da alimentação. Assim como as velas necessárias aos réus faziam parte dos róis dos cerieiros, como no auto, também de Lisboa, de 1758, no qual se pagou a um oficial 23.310 réis "da cera para o auto e penitenciados" 38 .

Esta categorização das despesas permite perceber a importância que as propinas e mercês dos oficiais ocupavam, o que não é de estranhar, uma vez que era prática recorrente no Antigo Regime. Pagava-se propinas nas mais variadas situações.

Esta categorização das despesas permite perceber a importância que as propinas e mercês dos oficiais ocupavam, o que não é de estranhar, uma vez que era prática recorrente no Antigo Regime. Pagava-se propinas nas mais variadas situações.

\footnotetext{
$34 \quad$ Para o ano de 1752: ANTT, Inq. Lisboa 364.

35 Para o ano de 1716: ANTT, Inq. Coimbra 430. Para o ano de 1751: ANTT, Inq. Coimbra 447.

36 Para o ano de 1665: ANTT, Inq. Évora 346.

37 ANTT, Inq. Lisboa 364.

38 ANTT, Inq. Lisboa 367.
} 


\section{Alimentação e Inquisição: Sociabilidades à mesa}

O último aspecto que se pretende desenvolver relaciona-se com as práticas alimentares seguidas nos autos-da-fé. Já se viu o que representavam estes momentos nas contas globais do Santo Ofício e qual a sua estrutura; analisar-se-ão, de seguida, as sociabilidades em torno das refeições, nos dias prévios à realização dos rituais ou no dia do acontecimento.

As fontes não são exaustivas quanto ao aspecto que se pretende desenvolver; no entanto, permitem, logo à partida, concluir que não havia uma refeição comum para todos os participantes nos cerimoniais. Veja-se, então, que momentos e pessoas distintas podem ser identificados.

Em primeiro lugar, os ministros e os oficiais não partilhavam a mesma refeição. Os primeiros tinham a sua própria refeição - em Lisboa incluía os membros do Conselho Geral - e as dos oficiais, que, por sua vez, também não incluíam todos os membros. Reflectiam, por isso, a demarcação das hierarquias, como aconteceria noutros espaços ${ }^{39}$.

As dos ministros teriam lugar na véspera do auto (jantar e ceia) e havia ainda o almoço do dia do cerimonial, que seria tomado logo pela manhã, que, nos finais de setecentos, estava definitivamente instalado como obrigatória ${ }^{40}$. Em 1729, o inquisidor-geral Cardeal da Cunha terá oferecido um jantar do auto "a 300 [pessoas] foi summamente magnifico" ${ }^{41}$.

É de admitir a hipótese de que, no dia do auto, os ministros comessem no cadafalso - como já referido - uma vez que dispunham de um local próprio, para degustar alguns pratos e refrescos. É de considerar, ainda, que boa parte das "bandejas de doces", mencionadas nas relações de despesa, além de serem destinadas ao jantar da véspera, fossem apreciadas durante o dia do auto, que começaria bem cedo pela manhã. Por exemplo, em 1737, em Lisboa, gastaram-se 16.350 réis em doces para a "ceia e almoço" ${ }^{42}$, portanto para o dia anterior e para o próprio de realização do cerimonial.

Ao nível dos oficiais, não se encontram dados acerca de refeições, por exemplo, dos notários ou do meirinho. Sabe-se, porém, que recebiam uma propina para jantar - como os ministros - mas não havia lugar a uma refeição para estes indivíduos. É de admitir que não acontecesse, uma vez que já recebiam um pagamento suplementar e porque as refeições encontradas para os demais oficiais respeitavam à necessidade de trabalho suplementar na realização do rito. Isto não significa, linearmente, que eles não participassem na preparação do auto, até porque eram os responsáveis pela redacção de

\footnotetext{
39 Algranti 2010.

40 Veloso 1992: 119.

41 Publ. Lisboa, Miranda, Olival 2002: 58.

42 ANTT, Inq. Lisboa 406.
} 
todos os documentos ${ }^{43}$. Também é certo, como se referiu, que os inquisidores e deputados recebiam a mesma propina e tinham direito a refeições, tendo, por isso direito à alimentação, mas também a um pagamento suplementar para o mesmo efeito ${ }^{44}$. Ao serem os cargos do topo da hierarquia inquisitorial, eram privilegiados.

Os oficiais que se identificam a partilhar refeições - nos dias que antecediam os cerimoniais - são os guardas dos cárceres, que recebiam um pagamento para o efeito e relativo a quinze dias, que em Lisboa, tendencialmente, era de 7.200 réis $^{45}$. Era um valor reduzido, quando comparado com os réditos despendidos apenas em doces ou outros alimentos para os ministros; como se verá. Contudo, nem sempre era suficiente, como aconteceu, em 1757, em Évora, que se gastaram 9.970 réis $^{46}$. Saliente-se que estes oficiais recebiam também uma propina ${ }^{47}$, mas como tinham tarefas suplementares que deveriam ser desempenhadas nos dias prévios ao auto, havia uma verba suplementar para alimentação. Estes valores também dependeriam da dimensão do cerimonial, uma vez que não eram todos iguais. Um auto maior significaria mais gastos.

Não se conhecem muitos róis das composições alimentares destas refeições, mas, para Évora, localizaram-se dois, para 1757 (Tabelas 6 e 7). Fica-se, assim, a saber que era o despenseiro do tribunal que tinha a tarefa de providenciar a compra e a confecção de todos os alimentos. Isto relacionava-se, directamente, com as suas tarefas quotidianas de abastecimento alimentar dos cárceres. Nos róis mencionados, o despenseiro Francisco José Marrecas tratou de todas as refeições dos guardas e também do pintor, indivíduo que também estava no tribunal nos dias que antecediam o auto, para pintar os retratos dos réus falecidos/ausentes, assim como das estátuas necessárias para as sentenças dos presos que eram sentenciados desta forma e, eventualmente, pintar os sambenitos.

43 Veja-se o exemplo de 1735 para Lisboa em que se pagaram 20.000 réis aos notários pela redacção das sentenças em: ANTT, Inq. Lisboa 354.

${ }_{44}$ Ano de 1744: ANTT, Inq. Lisboa 358.

45 Ano de 1746: ANTT, Inq. Lisboa 361.

46 ANTT, Inq. Lisboa 640.

$47 \quad$ Ano de 1733: ANTT, Inq. Lisboa 352. 


\begin{tabular}{|c|c|c|c|c|c|c|}
\hline \multirow{2}{*}{ Dias } & \multicolumn{2}{|l|}{ Almoço } & \multicolumn{2}{|l|}{ Jantar } & \multicolumn{2}{|l|}{ Ceia } \\
\hline & Descritivo & Valor & Descritivo & Valor & Descritivo & Valor \\
\hline \multirow[t]{2}{*}{$\begin{array}{c}21 / 09 / 1758 \\
\left(5 \cdot^{a} \text { feira }\right)\end{array}$} & - & - & $\begin{array}{c}1 \text { arrátel de vaca } \\
0,5 \text { arrátel de paio } \\
\text { Pão } \\
\text { Arroz } \\
\text { 1/4 de vinho } \\
\text { Pêras } \\
\end{array}$ & $\begin{array}{l}40 \\
50 \\
20 \\
20 \\
25 \\
20\end{array}$ & $\begin{array}{c}1 \text { frango } \\
\text { Salada e ovos } \\
\text { Pão } \\
\text { Melões } \\
1 / 4 \text { vinho } \\
\end{array}$ & $\begin{array}{l}20 \\
20 \\
20 \\
20 \\
20\end{array}$ \\
\hline & - & - & - & - & $\begin{array}{c}3 \text { tigelas de barro } \\
1 \text { cama }\end{array}$ & $\begin{array}{c}35 \\
180\end{array}$ \\
\hline $\begin{array}{c}22 / 09 / 1758 \\
\left(6 .^{a} \text { feira }\right)\end{array}$ & $\begin{array}{c}\text { Fatias de } \\
\text { manteiga e } \\
\text { ovos } \\
3 \text { arráteis de } \\
\text { peixe } \\
\text { Pão } \\
\text { Queijo } \\
\text { Fruta } \\
\text { 2,5 canadas de } \\
\text { vinho } \\
\end{array}$ & $\begin{array}{c}200 \\
180 \\
100 \\
50 \\
60 \\
350 \\
\end{array}$ & $\begin{array}{c}5 \text { arráteis de peixe } \\
\text { de sopas } \\
\text { Grãos } \\
\text { Ovos } \\
\text { Pão } \\
\text { Queijo } \\
\text { Fruta } \\
\text { Vinho }\end{array}$ & $\begin{array}{c}300 \\
\\
60 \\
50 \\
100 \\
50 \\
80 \\
350 \\
\end{array}$ & $\begin{array}{c}\text { Beringelas } \\
\text { Salada e ovos } \\
\text { Peixe frito } \\
\text { Pão } \\
\text { Queijo } \\
\text { Fruta } \\
\text { Vinho }\end{array}$ & $\begin{array}{c}60 \\
80 \\
180 \\
100 \\
50 \\
50 \\
350\end{array}$ \\
\hline $\begin{array}{c}\text { 23/09/1758 } \\
\text { (Sábado) }\end{array}$ & $\begin{array}{l}\text { Manteiga } \\
\text { Ovos } \\
\text { Peixe } \\
\text { Pão } \\
\text { Queijo } \\
\text { Fruta } \\
\text { Vinho } \\
\end{array}$ & $\begin{array}{c}80 \\
100 \\
180 \\
100 \\
50 \\
60 \\
350 \\
\end{array}$ & $\begin{array}{c}5 \text { arráteis de peixe } \\
\text { de sopas } \\
\text { Letria e manteiga } \\
\text { Pão } \\
\text { Fruta } \\
\text { Queijo } \\
\text { Vinho }\end{array}$ & $\begin{array}{c}300 \\
\\
120 \\
100 \\
60 \\
50 \\
350 \\
\end{array}$ & $\begin{array}{c}\text { Salada } \\
\text { Ovos } \\
1 \text { arrátel de peixe } \\
\text { Sopas } \\
\text { Pão } \\
\text { Queijo } \\
\text { Fruta } \\
\text { Vinho } \\
\end{array}$ & $\begin{array}{c}40 \\
50 \\
100 \\
40 \\
400 \\
50 \\
50 \\
350 \\
\end{array}$ \\
\hline $\begin{array}{l}24 / 09 / 1758 \\
\text { (Domingo) }\end{array}$ & $\begin{array}{l}1 \text { arrátel de } \\
\text { paio } \\
\text { Sopas } \\
\text { Pão } \\
\text { Queijo } \\
\text { Fruta } \\
\text { Vinho }\end{array}$ & $\begin{array}{c}100 \\
40 \\
100 \\
50 \\
50 \\
350\end{array}$ & $\begin{array}{c}5 \text { arráteis de vaca } \\
1 \text { arrátel de } \\
\text { presunto } \\
\text { Couve } \\
\text { Arroz } \\
\text { Pão } \\
\text { Queijo } \\
\text { Fruta } \\
\text { Vinho }\end{array}$ & $\begin{array}{c}180 \\
80 \\
30 \\
40 \\
100 \\
50 \\
60 \\
350\end{array}$ & $\begin{array}{c}1 \text { perua } \\
\text { Feitio da paste- } \\
\text { laria } \\
\text { 0,5 arrátel de } \\
\text { toucinho } \\
\text { Pão } \\
\text { Queijo } \\
\text { Fruta } \\
\text { Vinho }\end{array}$ & $\begin{array}{c}360 \\
50 \\
30 \\
100 \\
50 \\
80 \\
350\end{array}$ \\
\hline
\end{tabular}

Tabela 6: Refeições dos guardas da Inquisição de Evora e do pintor nos dias que antecederam o auto-da-fé de 25 de Setembro de 1758 (valores em réis)

Fonte: ANTT, Inq. Évora 640.

Não se sabe, porém, a quantos indivíduos se destinavam estas refeições, mas a julgar pelas demais listas de gastos do auto - nas quais se assinalam quatro guardas a receber propinas - é de admitir que, no final, estas se destinassem ao pintor e aos oficiais assinalados, num total de cinco pessoas.

Nos quatro dias que antecederam o auto-da-fé de Évora, de 25 de Setembro de 1758, o despenseiro tratou de alimentar os guardas (durante três dias, e não quinze como seria usual em Lisboa), e o pintor (Tabela 6). Este último 
teve direito às refeições do primeiro dia, assim como à cama onde pernoitaria (assinalada no rol), uma vez que os guardas residiam nas próprias casas da Inquisição, o que lhes era exigido pelo exercício das suas próprias funções.

Pela análise do rol dos alimentos percebe-se, por exemplo, que o consumo de doces era muito limitado, restringindo-se à ceia de Domingo. Por comparação, os ministros dos tribunais e do Conselho Geral degustavam uma diversidade maior destas iguarias e também em maior quantidade.

É interessante, ainda, verificar-se que se procurava consumir uma variedade de alimentos, com alternância de um dia comer carne e outro peixe. A fruta, o pão e o queijo eram elementos que todos os dias eram ingeridos, para além do vinho, a bebida por excelência ${ }^{48}$. Não se encontram referências a líquidos - como a aguardente ou o bagaço - e o queijo também era preferido, em detrimento dos paios e presuntos, tendencialmente, mais caros, a julgar pelos valores registados. Parece haver uma procura em torno da diversificação alimentar, que seria equilibrada do ponto de vista calórico ${ }^{49}$, pelo menos aos olhos da actualidade, pese embora a quase ausência de vegetais (excepção feita à beringela e à couve).

Para além de assegurar as refeições dos guardas, o despenseiro tinha ainda que garantir as dos impressores, que se deslocavam para o tribunal e ali pernoitavam. $\mathrm{Na}$ Tabela 7 assinala-se a composição das refeições, à semelhança da Tabela 6 , mas aqui desconhece-se, por completo, a quantas pessoas se destinavam.

\begin{tabular}{|c|c|c|c|c|c|c|}
\hline \multirow{2}{*}{ Dias } & \multicolumn{2}{|l|}{ Almoço } & \multicolumn{2}{|l|}{ Jantar } & \multicolumn{2}{|l|}{ Ceia } \\
\hline & Descritivo & Valor & Descritivo & Valor & Descritivo & Valor \\
\hline $\begin{array}{l}\text { 21/09/1758 } \\
\text { (5. } \text { feira) }\end{array}$ & - & |- & - & - & $\begin{array}{l}3 \text { capões } \\
1,5 \text { arrátel de arroz } \\
\text { [Ilegível] e salada } \\
\text { Pão } \\
0,5 \text { queijo } \\
\text { Fruta } \\
2,5 \text { canadas } \\
\text { de vinho }\end{array}$ & \begin{tabular}{|l|}
480 \\
60 \\
100 \\
100 \\
50 \\
60 \\
350
\end{tabular} \\
\hline $\begin{array}{l}\text { 22/09/1758 } \\
\text { (6. } \text {. }^{\text {feira })}\end{array}$ & $\begin{array}{l}1 \text { arrátel de } \\
\text { manteiga } \\
\text { Ovos } \\
\text { Pão } \\
3 \text { arráteis de } \\
\text { peixe frito } \\
\text { Queijo } \\
\text { Fruta } \\
2,5 \text { canadas } \\
\text { de vinho }\end{array}$ & $\begin{array}{l}80 \\
100 \\
100 \\
180 \\
\\
50 \\
80 \\
350\end{array}$ & $\begin{array}{l}\text { Ervilhas } \\
\text { e ovos } \\
5 \text { arráteis de } \\
\text { peixe de sopas } \\
\text { Pão } \\
\text { Pêras e melões } \\
\text { Queijo } \\
\text { Vinho }\end{array}$ & $\begin{array}{l}200 \\
300 \\
\\
100 \\
120 \\
50 \\
350\end{array}$ & $\begin{array}{l}\text { Manteiga e arroz } \\
\text { Salada e ovos } \\
\text { Peixe frito } \\
\text { Pão } \\
\text { Queijo } \\
\text { Fruta } \\
\text { Vinho }\end{array}$ & $\begin{array}{l}100 \\
100 \\
180 \\
100 \\
50 \\
100 \\
350\end{array}$ \\
\hline
\end{tabular}

48 Vid.: Cardoso 1997.

49 Feitas as ressalvas devidas à noção coeva de equilíbrios alimentares. Sobre o tema, ainda que aplicado à corte, vid.: Felismino 2011. 


\begin{tabular}{|c|c|c|c|c|c|c|}
\hline $\begin{array}{l}\text { 23/09/1758 } \\
\text { (Sábado) }\end{array}$ & $\begin{array}{l}\text { Fatias de manteiga } \\
\text { com açúcar e ovos } \\
\text { Peixe frito } \\
\text { Pão } \\
\text { Queijo } \\
\text { Fruta } \\
\text { Vinho }\end{array}$ & $\begin{array}{l}240 \\
180 \\
100 \\
50 \\
60 \\
350\end{array}$ & $\begin{array}{l}5 \text { arráteis de } \\
\text { peixe de sopas } \\
\text { Letria e } \\
\text { manteiga } \\
\text { Melões } \\
\text { Pão } \\
\text { Queijo } \\
\text { Vinho }\end{array}$ & $\begin{array}{l}300 \\
120 \\
100 \\
100 \\
50 \\
350\end{array}$ & $\begin{array}{l}\text { Couve murciana } \\
\text { e arroz } \\
\text { Peixe frito } \\
\text { Pastéis } \\
\text { Uvas } \\
\text { Pão } \\
\text { Queijo } \\
\text { Vinho }\end{array}$ & $\begin{array}{l}150 \\
180 \\
100 \\
80 \\
100 \\
50 \\
350\end{array}$ \\
\hline $\begin{array}{l}\text { 24/09/1758 } \\
\text { (Domingo) }\end{array}$ & $\begin{array}{l}5 \text { arráteis } \\
\text { de vitela } \\
\text { Feitio da } \\
\text { pastelaria } \\
5 \text { arráteis de } \\
\text { vaca cozida } \\
\text { Presunto } \\
1 \text { arrátel de } \\
\text { paio } \\
\text { Couve } \\
\text { murciana } \\
\text { Pão } \\
\text { Queijo } \\
\text { Fruta } \\
\text { Arroz } \\
5 \text { canadas } \\
\text { de vinho }\end{array}$ & $\begin{array}{l}200 \\
100 \\
180 \\
80 \\
100 \\
30 \\
200 \\
100 \\
300 \\
60 \\
700\end{array}$ & $\begin{array}{l}5 \text { arráteis } \\
\text { de vitela } \\
\text { Feitio da } \\
\text { pastelaria } \\
5 \text { arráteis } \\
\text { de vaca cozida } \\
\text { Presunto } \\
1 \text { arrátel } \\
\text { de paio } \\
\text { Couve } \\
\text { murciana } \\
\text { Pão } \\
\text { Queijo } \\
\text { Fruta } \\
\text { Arroz } \\
5 \text { canadas } \\
\text { de vinho }\end{array}$ & $\begin{array}{l}200 \\
100 \\
180 \\
80 \\
100 \\
30 \\
200 \\
100 \\
300 \\
60 \\
700\end{array}$ & $\begin{array}{l}\text { [Ilegível] } \\
\text { Arroz } \\
\text { Presunto } \\
\text { Salada } \\
\text { Pão } \\
\text { Queijo } \\
\text { Pêras e uvas } \\
\text { Vinho }\end{array}$ & $\begin{array}{l}480 \\
60 \\
80 \\
30 \\
100 \\
50 \\
100 \\
350\end{array}$ \\
\hline $\begin{array}{l}\text { 25/09/1758 } \\
\text { (2. } .^{\text {a feira })}\end{array}$ & $\begin{array}{l}\text { Paio e sopas } \\
\text { Pastéis } \\
\text { Pão } \\
\text { Pêras e melões } \\
\text { Queijo } \\
\text { Vinho }\end{array}$ & $\begin{array}{l}160 \\
120 \\
100 \\
100 \\
50 \\
350\end{array}$ & $\begin{array}{l}5 \text { arráteis } \\
\text { de vaca } \\
2 \text { arráteis } \\
\text { de presunto } \\
\text { e paio } \\
\text { Couve } \\
\text { murciana } \\
\text { Arroz } \\
\text { Pão } \\
\text { Queijo } \\
\text { Fruta } \\
2,5 \text { canadas } \\
\text { de vinho }\end{array}$ & $\begin{array}{l}180 \\
180 \\
30 \\
60 \\
100 \\
50 \\
80 \\
350\end{array}$ & $\begin{array}{l}5 \text { frangos } \\
\text { Presunto } \\
\text { Salada } \\
\text { Paio } \\
\text { Pão } \\
\text { Queijo } \\
\text { Fruta } \\
\text { Vinho }\end{array}$ & $\begin{array}{l}400 \\
80 \\
30 \\
100 \\
100 \\
50 \\
60 \\
350\end{array}$ \\
\hline $\begin{array}{l}\text { 26/09/1758 } \\
\text { (3. afeira) }\end{array}$ & $\begin{array}{l}\text { Manteiga } \\
\text { Ovos } \\
\text { Peixe frito } \\
\text { Pão } \\
\text { Queijo } \\
\text { Fruta } \\
\text { Vinho }\end{array}$ & $\begin{array}{l}80 \\
100 \\
120 \\
100 \\
50 \\
80 \\
350\end{array}$ & $\begin{array}{l}\text { Vaca } \\
\text { Toucinho } \\
\text { Presunto } \\
\text { Couve } \\
\text { Arroz } \\
\text { Fruta } \\
\text { Pão } \\
\text { Queijo } \\
\text { Vinho }\end{array}$ & $\begin{array}{l}180 \\
30 \\
80 \\
30 \\
60 \\
100 \\
100 \\
50 \\
350\end{array}$ & $\begin{array}{l}5 \text { arráteis } \\
\text { de carneiro } \\
\text { Arroz } \\
\text { Salada } \\
\text { Paio } \\
\text { Pão } \\
\text { Queijo } \\
\text { Fruta } \\
\text { Vinho }\end{array}$ & $\begin{array}{l}180 \\
60 \\
20 \\
100 \\
100 \\
50 \\
60 \\
350\end{array}$ \\
\hline
\end{tabular}

Tabela 7: Refeições dos impressores que trabalharam no auto-da-fé de 25 de Setembro de 1758 (valores em réis)

Fonte: ANTT, Inq. Évora 640. 
A análise das refeições preparadas para os impressores é semelhante à referida anteriormente, nomeadamente, acerca do consumo de doces, de carne e de peixe, assim como a preferência pelo queijo, o vinho, o pão e a fruta. Nota-se, contudo, um ligeiro aumento no consumo de vegetais/leguminosas (couve, ervilhas e salada), assim como aparece mais vezes o porco, sob a forma de paio e de presunto. Assinale-se, ainda, a presença da aguardente; que no rol anterior estava ausente.

Saliente-se, ainda, que o almoço do dia do auto foi mais modesto, o que poderá indiciar que os impressores estavam mais ocupados com o trabalho e, por isso, teve de ser uma refeição menos demorada.

Reforça-se a ideia que ambos os róis foram elaborados pelo mesmo despenseiro, mas são distintos, o que significa que os guardas e o pintor/ impressores não partilhavam as mesmas refeições.

O que se acabou de assinalar corrobora a hipótese levantada que o auto-da-fé originava vários momentos e espaços de sociabilidade entre os diversos agentes envolvidos na preparação do cerimonial. Menos conhecida seria, todavia, a ideia de estes vários momentos se traduzirem, também, na partilha de refeições.

Assim é possível identificar vários universos: por um lado, os ministros, quer dos tribunais distritais, quer do Conselho Geral, tinham direito às refeições, a que se acrescia o pagamento de propinas. Por outro, os oficiais, como os notários ou o meirinho, que apenas recebiam estes estipêndios, sem que lhes fosse concedida uma refeição. Ainda por outro, os guardas que trabalhavam na preparação do auto, para os quais, além das referidas propinas, o Santo Ofício ainda suportava as suas refeições nos dias imediatamente anteriores à realização do auto.

Finalmente, os agentes externos à Inquisição, que, por via da necessidade de se deslocarem e pernoitarem nos edifícios da Inquisição, partilhavam também das refeições. Eram eles os impressores (que também levavam a maquinaria necessária ao seu trabalho), os pintores e, ainda, em Coimbra e Lisboa, os eclesiásticos recrutados a instituições locais (Companhia de Jesus, Convento de Santa Justa...), que, na véspera no auto, iam também dormir ao tribunal. Destes últimos, não se conhece nenhum rol das refeições, mas pela prática descrita é de supor que também tivessem refeições independentes das dos demais.

A partir de 1741, em Lisboa (não se encontram dados para os demais tribunais), os presos passaram a ter também direito a uma refeição durante a sua permanência nos cárceres da penitênci ${ }^{50}$ (havia dois: os secretos e o da penitência), para o qual eram tresladados os réus que iam ser sentenciados no auto. Este valor era pago ao alcaide da penitência dos cárceres que tratava das refeições ${ }^{51}$.

\footnotetext{
$50 \quad$ ANTT, Inq. Lisboa 351.
}

51 Vid. um exemplo de 1752 em: ANTT, Conselho Geral do Santo Ofício, Livros e papéis de contas, mç. 1, cx. 2, n. ${ }^{\circ} 121$, fl. $14 \mathrm{v}$. 
Ao alcaide dos cárceres foi ainda pago, em Coimbra, em 1728, 4.500 réis pela ceia que deu aos médicos, cirurgião e barbeiro ${ }^{52}$, que, apesar de serem oficiais encartados pela Inquisição, como os seus congéneres, não estavam, permanentemente, nos tribunais. Iam ali quando era necessário.

Após a análise centrada nos agentes, dar-se-á corpo ao estudo relativo aos alimentos que constam nos róis de despesas. Os documentos que se analisaram anteriormente - referentes aos impressores e guardas/pintor - são avulsos e dão uma perspectiva micro do objecto em estudo. Além disso, são uma visão mais restrita centrada em determinados oficiais e agentes recrutados, externamente, à Inquisição.

Os dados que se apresentam nas Tabelas 8 a 10 fazem um recorte, ou seja, a partir da grelha classificativa dos custos totais do auto, focalizam-se nas despesas que se classificaram como sendo de alimentação.

\begin{tabular}{|c|c|c|c|c|c|c|c|c|c|c|c|}
\hline 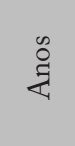 & 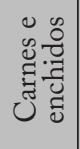 & 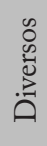 & $\begin{array}{l}\mathscr{U} \\
\text { O } \\
0\end{array}$ & 茎 & 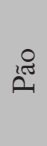 & $\begin{array}{l}\text { U. } \\
\text { م. }\end{array}$ & $\begin{array}{l}\stackrel{\circ}{J} \\
\dot{>} \\
\dot{>}\end{array}$ & 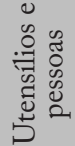 & 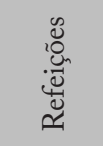 & 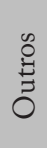 & 忐 \\
\hline 1716 & & & 20.000 & & & & & & 6.000 & & 26.000 \\
\hline 1726 & & & & & & & & & 6.000 & & 6.000 \\
\hline 1727 & & & 35.000 & & & & & & 6.000 & & 41.000 \\
\hline 1728 & & & & & & & & & 45.500 & & 45.500 \\
\hline 1729 & & & 35.000 & & & & & & 6.000 & & 41.000 \\
\hline 1730 & & & 35.000 & & & & & & 6.000 & & 41.000 \\
\hline 1732 & & & 35.000 & & & & & & 6.000 & & 41.000 \\
\hline 1737 & & & 35.000 & & & & & & 6.000 & & 41.000 \\
\hline 1742 & & & 35.000 & & & & & & 6.000 & & 41.000 \\
\hline 1744 & & & & & & & & & & & 0 \\
\hline 1749 & & & & & & & & & 47.060 & & 47.060 \\
\hline 1751 & & & 35.000 & & & & & & 6.000 & & 41.000 \\
\hline 1751 & & & & & & & & & 41.000 & & 41.000 \\
\hline 1755 & & & 35.000 & & & & & & 6.000 & & 41.000 \\
\hline
\end{tabular}

Tabela 8: Estrutura dos gastos do auto-da-fé do Tribunal de Coimbra (1700-1760) - valores nominais (réis)

Fonte: ANTT, Inq. Coimbra 490, 434-437, 439, 442, 444-445, 447, 448; Inq. Lisboa, mç. 6, n.o 24 . 
"Alimentar" o auto-da-fé: uma incursão pelos gastos do principal cerimonial da Inquisição portuguesa no século XVIII

\begin{tabular}{|c|c|c|c|c|c|c|c|c|c|c|c|}
\hline 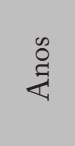 & 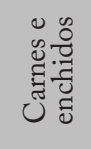 & 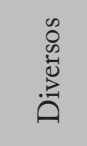 & $\begin{array}{l}\mathscr{U} \\
\text { ̊ } \\
0\end{array}$ & 蛋 & $\overbrace{1}^{0}$ & ص. & $\stackrel{8}{\Xi}$ & 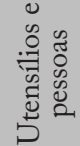 & 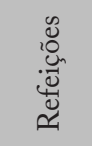 & 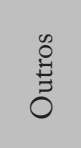 & 电 \\
\hline 1710 & 5.450 & 9.800 & 76.390 & 800 & & 43.980 & 7.125 & 1.920 & 22.260 & & 167.725 \\
\hline 1724 & 25.380 & 19.540 & 115.250 & & & 57.825 & 6.280 & 1.370 & & 8.580 & 234.225 \\
\hline 1725 & & & 11.200 & & & 9.630 & & & 15.420 & & 36.250 \\
\hline 1744 & & & & & & & & & 44.134 & & 44.134 \\
\hline 1752 & 5.450 & 9.800 & 76.390 & & & & & & 50.391 & & 50.391 \\
\hline
\end{tabular}

Tabela 9: Estrutura dos gastos do auto-da-fé do Tribunal de Évora (1700-1760) - valores nominais (réis)

Fonte: ANTT, Inq. Évora 365, 368-369, 373, 375.

\begin{tabular}{|c|c|c|c|c|c|c|c|c|c|c|c|}
\hline 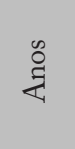 & 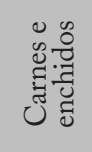 & 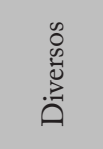 & $\begin{array}{l}\mathscr{U} \\
\tilde{O} \\
0\end{array}$ & 茎 & 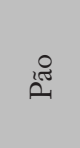 & 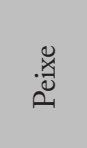 & $\underset{j}{\stackrel{\Xi}{\Xi}}$ & 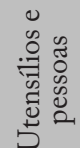 & 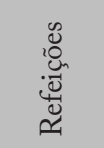 & $\stackrel{0}{\mathscr{B}}_{0}^{\infty}$ & 里 \\
\hline 1716 & & 3.080 & 75.100 & & & & & & 24.570 & 3.080 & 105.830 \\
\hline 1720 & 17.140 & 5.700 & 102.570 & 5.880 & 1.700 & 9.990 & & 2.400 & 38.430 & & 183.810 \\
\hline 1725 & 21.986 & & 176.515 & 3.400 & 1.100 & 14.400 & 1.100 & 820 & 35.160 & & 254.481 \\
\hline 1726 & 10.140 & & 20.820 & 1.210 & 1.210 & & & 1.620 & 42.950 & & 77.950 \\
\hline 1728 & 23.440 & 14.240 & & 1.200 & & & & & 16.130 & & 55.010 \\
\hline 1729 & 14.000 & & 20.650 & 960 & 320 & & & & 57.771 & & 93.701 \\
\hline 1733 & & 20.895 & 16.000 & & & & & & 98.244 & & 135.139 \\
\hline 1735 & & 42.250 & & & & & & & 110.980 & & 153.230 \\
\hline 1737 & 13.690 & & 16.350 & 1.820 & 600 & 3.960 & 800 & 7.225 & 27.300 & & 71.745 \\
\hline 1741 & 17.600 & 24.060 & & & & & & & 58.600 & & 100.260 \\
\hline 1744 & & & & & & & & & 114.148 & & 114.148 \\
\hline 1746 & & 159235 & & & & & & & 20.000 & & 179.235 \\
\hline 1748 & & 45.000 & & & & & & & 23.600 & & 68.600 \\
\hline 1750 & & & & & & & & & 21.600 & & 21.600 \\
\hline 1752 & & 106.132 & & & & & & & 23.200 & & 129.332 \\
\hline 1758 & & 25.930 & 75.100 & & & & & & 1.200 & & 27.130 \\
\hline
\end{tabular}

Tabela 10: Estrutura dos gastos do auto-de-fé do Tribunal de Lisboa (1700-1760) - valores nominais (réis)

Fonte: ANTT, Inq. Lisboa 338, 340, 345-346, 348-349, 352, 354, 358, 360-364, 367, 406. 
A maior parte das categorias são auto-explicativas, mas é necessário fazer algumas considerações. O que se designa por diversos, inclui os gastos relativos a vários bens que não foi possível individualizar. Por exemplo, quando em Évora, em 1710, se pagou a Maria das Neves, conserveira, 9.800 réis "de uns pratos que fez para a função do auto" ${ }^{53}$; ou quando, em 1724, se pagou ao pasteleiro Francisco Rodrigues 10.960 réis por "um rol de algumas coisas de cozinha que fez [...] e uns queijos frescos" 54 .

No que respeita à categoria de refeiçôes, somaram-se os dados referentes a almoços, jantares ou ceias, que aparecem, simplesmente, designados como tal. Por exemplo, em Lisboa, em 1748, refere-se apenas "da despesa da ceia e do jantar"

Finalmente, na classe de utensílios e pessoas, encaixaram-se os valores referentes à aquisição de instrumentos de cozinha, assim como, estafetas ou pessoas contratadas para carregar e/ou transportar os alimentos, para os edifícios da Inquisição. Incluíram-se, também, mulheres contratadas, para a confecção da comida.

É pela explicação dada, anteriormente, que se compreende o gráfico referente a Coimbra (Tabela 10). Nas listas dos gastos do auto, os únicos elementos que aparecem discriminados, individualmente, são os doces; os demais alimentos, quando surgem, são apenas assinalados como jantar dos padres, ceia do secreto e outras designações afins. Por vezes, o que aparece assinalado, são as refeições dos padres de Santa Justa que iam ajudar no auto-da-fé, na leitura das sentenças e os doces adquiridos, para consumo no secreto. Nada mais. Pelo demonstrado, reforça-se a ideia que as demais despesas teriam de existir, mas, até ao momento, não foi possível localizar os róis onde se assinalam, assim como os meios através o Tribunal procedia ao seu pagamento.

A partir dos anos de 1740, também as listas de Évora e Lisboa deixam de ser exaustivas (Tabelas 9 e 10). Há ainda uma série de refeiçôes, para a última mesa, cujos conteúdos detalhados se ignoram. Eram transacções monetárias destinadas ao pagamento das refeições dos padres que ajudavam no auto, dos pintores, dos presos e afins, como também já se referiu. A ausência de pormenor relaciona-se com questões práticas: nos livros de casa, através dos quais se está a levar a cabo esta análise, registavam-se, em matéria de gastos, sobretudo somatórios finais. Estes valores eram o dado relevante para prestar contas junto do Conselho Geral. O grau de minúcia dependia do tesoureiro em funções. Os róis detalhados existiam, mas muitos ter-se-ão perdido.

Há ainda a assinalar a preferência, muito clara, poder-se-ia dizer, pelo consumo de doces. Coloca-se, assim, a hipótese de estes se destinarem - na

\footnotetext{
$53 \quad$ ANTT, Inq. Évora 365.

ANTT, Inq. Évora 368.

ANTT, Inq. Lisboa 362.
} 
sua grande maioria - aos cargos de topo do corpus inquisitorial, pois, como se viu, dos róis analíticos dos guardas e impressores/pintor, estes consumiram uma vez, apenas, algum alimento deste tipo. Era um alimento fortemente demarcador das hierarquias.

O tribunal de Évora foi o que consumiu mais doces, que para além de serem encomendados aos conventos da cidade, também se pediam a Coimbra.

\begin{tabular}{|l|l|}
\hline Doces & Valor(réis) \\
\hline A bandeja do primeiro dia de vários doces & 9.960 \\
\hline 2 fruteiros um de laranjas, e limões, e outro de queijinhos & 8.640 \\
\hline 2 fruteiros 1 de toucinho do céu, e outro de talhadas de bom gosto & 12.420 \\
\hline 1 fruteiro de bocados de chila caiota e queijinhos & 7.000 \\
\hline 2 pratos de batatada & 2.940 \\
\hline 2 pratos de ovos & 2.880 \\
\hline Rol da importância dos doces & 43.480 \\
\hline
\end{tabular}

Tabela 11: Rol de doces encomendado pelo tribunal de Évora ao Convento de Santa Clara de Coimbra em 1757

Fonte: ANTT, Inq. Évora 640.

Em 1710, foi por via do promotor do tribunal de Coimbra que se transportaram os doces, para o auto-da-fé de Évora daquele ano, pelos quais se pagaram 52.710 réis. Não sendo suficientes, ainda se pagaram mais 11.680 réis ao confeiteiro Pedro Rodrigues e 12.000 réis à soror Inácia Francisca de São José, do Convento do Paraíso ${ }^{56}$, ambos de Évora ${ }^{57}$. Também, em 1757, ao Convento de Santa Clara, em rol assinado por soror Teresa Cecília do Sacramento, se fez um pedido de doces, no valor de 43.480 réis (Tabela 11). Os doces de Santa Clara eram muito apreciados ${ }^{58}$ e justificavam um ministro da Inquisição ocupar-se do seu transporte de terras do Mondego até Évora.

Em 1724, foi um deputado eborense, Tomé Chicorro da Gama Lobo, que encomendou "doze caixas de doces secos", pelas quais pagou o Tribunal 28.950 réis (2.412,5 réis/cada). No mesmo ano, ainda se encomendaram mais treze arrobas de açúcar, que custaram 58.740 réis, para além dos 24.440 réis entregues a uma confeiteira e a uma religiosa da cidade por mais doces ${ }^{59}$. Por esta razão, os réditos despendidos neste ano superaram os pagos em propinas aos ministros e oficiais do Tribunal (Tabela 10).

\footnotetext{
56 Vid.: Saramago 1997: 65-68.

57 ANTT, Inq. Evora 365.

58 Veja-se, a título de exemplo: Sousa 2011.

59 ANTT, Inq. Évora 368.
} 


\begin{tabular}{|c|c|c|}
\hline Doces & Valor(réis) & Valor/pessoa \\
\hline Bandeja de doces que foi para o Conselho Geral [6] & 14.400 & 2.400 \\
\hline 4 bandejas para os quatro inquisidores & 57.600 & 14.400 \\
\hline Bandeja que foi para o promotor & 12.000 & 12.000 \\
\hline Bandejas que foram para os 6 notários & 57.600 & 9.600 \\
\hline $\begin{array}{c}\text { Dos doces que foram depois da publicação do auto; e 2 bandejas } \\
\text { uma para a ceia na véspera do auto e outra para o almoço }\end{array}$ & 34.915 & - \\
\hline Total & 176.515 & - \\
\hline
\end{tabular}

Tabela 12: Doces comprados pelo tribunal de Lisboa para o auto-da-fé de 1725 Fonte: ANTT, Inq. Lisboa 345.

Mas não era só em Évora que se apreciavam estas iguarias. Em Lisboa, à semelhança dos quinze dias de preparação do auto - durante os quais se alimentavam os guardas - também na aquisição dos doces se tinha em linha de conta este tempo. Em 1720, gastaram-se 6.240 réis em doces para os "quinze dias do auto" ${ }^{\prime 6}$, valor modesto, quando comparado com os despendidos, em Évora, para o dia do cerimonial.

Quando se analisam, porém, os gastos em doces no auto de Lisboa, de 1725 (Tabela 12), verifica-se que são superiores, aos assinalados para o de Évora, de 1757. Dividindo-se o valor aplicado, nestas verbas, pelo número de pessoas a quem se destinavam, conclui-se que eram os inquisidores que recebiam maior quantidade de doces por pessoa, logo seguidos do promotor, dos notários e, no final, dos membros do Conselho Geral.

São valores elevados, sobretudo tendo-se em atenção que, por exemplo, em 1725, o arrátel de açúcar custaria, em Lisboa, cerca de 111 réis ${ }^{61}$. Ou ainda, perto do Carnaval de 1715, em Arraiolos, pequena povoação no interior de Portugal, cerca de Évora, "o arrátel de queijadinhas e broinhas e cavacas" custaria cerca de 120 réis $^{62}$. Na cidade de Évora, em 1724, pagou o Tribunal $2.412,5$ réis por cada caixa de doces $\operatorname{secos}^{63}$. Mas doces, como os famosos "ovos" de Santa Clara de Coimbra, em 1757, um prato desta iguaria custaria 1.440 réis, valor superior pela matéria-prima utilizada e pelo trabalho associado à sua confecção ${ }^{64}$. Estes réditos permitem contextualizar, um pouco, os montantes despendidos pela Inquisição apenas nestas iguarias.

\footnotetext{
60 ANTT, Inq. Lisboa 340.

${ }^{61}$ Preços de açúcar disponíveis na secção "honey and sugar" do site do projecto Prices, Wages and Rents in Portugal 1300-1910, Disponível em: <http://pwr-portugal.ics.ul.pt/?page_id=56>, Acesso em: 25 nov. 2015.

${ }_{62}$ Arquivo Histórico Municipal de Arraiolos [AHMA], Liv. vereações 23: 121.

63 ANTT, Inq. Évora 368.

64 ANTT, Inq. Évora 640.
} 
Saliente-se, todavia, que se ignora a composição pormenorizada destas bandejas de doces. Pode dizer-se, contudo, que as verbas gastas constituíam-se como as mais dispendiosas, sendo, tendencialmente, mais avultadas, do que a própria carne/peixe. Parece que os ministros inquisitoriais partilhavam da “obsessão" por doçaria que Portugal conheceria, pelo menos, desde o século XVI, no dizer de Isabel Drummond Braga ${ }^{65}$, e que Carlos Veloso também assinala, recorrendo aos relatos de viajantes em Portugal nesta centúria ${ }^{66}$.

Para Coimbra não se dispõe de dados com este nível de detalhe.

As refeições não se compunham, obviamente, apenas de doces. Curiosamente, era em Évora que se consumia mais peixe, não obstante ser, das três cidades, a que se situava mais distante do mar ou de um rio. Comprava-se, por exemplo, em Setúbal, como, em 1724, quando o pescadeiro do Tribunal gastou 40.020 réis num rol de empadas e peixe frito ${ }^{67}$. Aliás, eram estas as formas sob as quais se consumia o peixe, nas três mesas inquisitoriais. Globalmente, entre os peixes preferidos estavam os linguados, os salmonetes, tendencialmente, mais caros ${ }^{68}$, e os besugos, mais baratos.

As empadas não eram apenas de peixe, mas também de carne, que seriam muito apreciadas na corte de D. João V, como refere Ana Isabel Buescu ${ }^{69}$. Em Lisboa, para o auto de 1725, gastaram-se 13.386 réis em empadas de pombo e de vitela, mais a sua confecção. Após os doces, foram o alimento mais dispendioso, logo seguidos de 6.240 réis em perus, para assar para o almoço do cerimonial ${ }^{70}$.

Nas carnes, nota-se, globalmente, o consumo de variedade. Degustavase caça (pombo e perdizes), vitela, aves de capoeiro, como frangos, galinhas ou perdigotos. $\mathrm{O}$ porco era consumido sob o formato de enchidos (paios e presuntos) e toucinho. Esta diversificação vai ao encontro do apontado, por David Felismino, acerca da introdução gradual na dieta - nos séculos XVI e XVIII - de carnes de talho, em detrimento das de caça. Esta alteração levou ao abandono das teorias dietéticas, nas quais se desaconselhava o consumo de carnes de talho, entre outras razões, por serem geradoras da melancolia ${ }^{71}$.

No entanto, há que ter em linha de conta que os gastos não eram sempre elevados. Por exemplo, em Lisboa, em 1735, gastaram-se 42.250 réis em "perus, galinhas, frangos, peixe, doces e fruta e mais coisas para o jantar e ceia"72. Era um valor, relativamente, baixo, quando comparado com os demais, que têm

\footnotetext{
Braga 2007: 19.

Veloso 1992: 124.

ANTT, Inq. Évora 368.

Silva 2008: 236.

Buescu 2011: 306.

ANTT, Inq. Lisboa 345.

Felismino 2011: 370.

ANTT, Inq. Lisboa 354.
} 
vindo a ser analisados. Tudo dependeria da dimensão do auto, do número de presos que deveriam ouvir as suas sentenças, assim como da disponibilidade de capital nos Juízos do Fisco.

Em suma, comprova-se a inexistência de uma refeição comum, mas identifica-se a existência de vários momentos de partilha de refeições, com diferentes intervenientes, quer da Inquisição, quer pessoal contratado externamente. Eram, deste modo, espaços de sociabilidade à mesa diferenciados, durante os quais os alimentos consumidos eram também eles diferenciadores, sobretudo em matéria de doces, e marcavam as hierarquias. Pode mesmo dizer-se que esta era a categoria alimentar que representava mais gastos, em todos os tribunais do Santo Ofício. Não se pode, contudo, afirmar se havia, por exemplo, um afastamento do que era considerada a dieta alimentar indicada, como terá sido identificado para a mesa régia ${ }^{73}$.

\section{Considerações finais}

O auto-da-fé público era o cerimonial mais importante da Inquisição portuguesa. Era aqui que o Tribunal legitimava, junto da sociedade, a sua existência. Os réus ouviam ali as suas sentenças e era no confisco dos seus bens (aqueles a quem era aplicada esta pena), que residiam as fontes de financiamento dos mesmos. Não cabia às rendas dos tribunais, propriamente ditas, pagar a realização destes rituais. Havia uma fonte de capital "autónoma" - administrada pelos Juízos do Fisco - que servia para custear a realização destes cerimoniais. Esta será a primeira grande conclusão deste estudo, pese embora a teia complexa das relações entre o Santo Ofício, a Coroa e os Juízos do Fisco.

Viu-se, também, que, apesar do papel central dos autos-da-fé, estes não eram um esforço financeiro extraordinário para os tribunais inquisitoriais. Lisboa, como capital do reino, conhecia os cerimoniais com custos mais elevados; Coimbra e Évora tinham valores aproximados. Contudo, era em Évora que realizá-los significava, do ponto de vista das percentagens, um encargo financeiro maior, no século XVIII. Ou seja, das rendas recebidas por este tribunal, dispunha-se uma parcela maior que nos demais para os custos de realização do auto.

Quando se escrutinaram as categorias principais de despesas relacionadas com os autos - não foram analisadas as custas dos processos-crime - concluiu-se que eram três. Por um lado, as propinas e mercês que eram pagas às hierarquias inquisitoriais (o que não foi surpreendente, uma vez que

\footnotetext{
$73 \quad$ Felismino 2011.
} 
a maior despesa em todos os tribunais e para o período, para já conhecido, de 1670-1770, era os encargos com pessoal). Seguiam-se os gastos com a imprensa, relacionados com todos os materiais e trabalho dos impressores nos dias de preparação e realização dos autos. A alimentação ocupava a terceira parcela relevante. Confirmou-se a hipótese da inexistência de um espaço comum (entre ministros, oficiais e outros) na partilha de refeições. Havia, sim, vários momentos, com diferentes intervenientes.

Também os alimentos consumidos eram indicadores das hierarquias, sobretudo os doces, maioritariamente, reservados aos cargos inquisitoriais de topo. Era assim nos tribunais inquisitoriais, como seria noutros espaços e vivências da multiplicidade da sociedade da Época Moderna. A procura de doces justificava a compra dos mesmos a outras cidades, chegando, mesmo, a envolver os ministros inquisitoriais nestas dinâmicas.

Pelos poucos róis de alimentos que foi possível localizar, constata-se que havia alguma procura de equilíbrio alimentar, com o consumo alternado de carne e peixe, e também de algumas verduras. Muitos dos produtos eram consumidos sob a forma de empadas ou enchidos. O queijo e o pão eram elementos muito presentes, para além de o vinho ser o líquido degustado, por excelência.

\section{REFERENCIAS}

\section{Fontes MANUSCRITAS}

Arraiolos, AHMA, Livros de vereaçōes de Arraiolos, livro 23.

Lisboa, ANTT, Conselho Geral do Santo Ofício, Livros e papéis de contas, mç. 1, cx. 2, n. ${ }^{\circ} 121$. Lisboa, ANTT, Inquisiçẫo de Coimbra, livros 154, 430, 435, 445, 447; mç. 65, n. ${ }^{\circ} 1$.

Lisboa, ANTT, Inquisição de Évora, livros 346, 365, 368, 640.

Lisboa, ANTT, Inquisição de Lisboa, livros 158, 330, 340, 345, 351, 352, 354, 358, 361, $362,364,367,406,640 ;$ mç. 5 , n.o 24.

\section{FONTES IMPRESSAS}

Franco, J. E., Assunção, P. (2004), As metamorfoses de um polvo: religião e politica nos regimentos da Inquisição Portuguesa (séculos XVI-XIX), Prefácio, Lisboa.

Lisboa, J. L., Miranda, T. C. P. R., Olival, F. (eds.) (2002), Gazetas manuscritas da Biblioteca Pública de Évora: 1729-1731, vol. 1, CIDEHUS-UE, Colibri, CHCUNL, Lisboa. 


\section{ObRAS DE REFERENCIA E ESTUdOS}

Águeda Méndez, M. (2004), "El Auto General de Fe de 1649: Inquisición y Teatralidad En La Nueva España”, Theatralia: Revista de Poética del Teatro 6: 169-180.

Algranti, L. M. (2010), "Notas sobre a mesa da Casa Real Portuguesa no reinado de D. José I", in I. G. Sá; M. F. Garcia (eds.), Portas Adentro: Comer, Vestir, Habitar (ss. XVI-XIX), Imprensa da Universidade de Coimbra/Secretariado de Publicaciones e Intercambio Editorial [da] Universidad de Valladolid, Coimbra/Valladolid, 87-113.

Anderson, R.W. (2012), "Inquisitorial Punishments in Lisbon and Évora”, E-JPH10.1: 19-36.

Antunes, C.; Silva, F. R. (2012), "In Nomine Domini et In Nomine Rex Regis: Inquisition, Persecution and Royal Finances in Portugal, 1580-1715", in F. Ammannati (ed.), Religione E Istituzioni Religiose nell'Economia Europea: 10001800, Firenze University Press, Firenze, 377-410.

Arias Pardo, M. C., Fernández Carrasco, E. (2009), "La Inquisición en Cuenca: el auto de fe de 12 de agosto de 1590", Revista de Derecho UNED 4: 45-78.

Barros Carollo, D. H. M. (1999), "Auto-da-Fé: a ceremony more than just words", Revista de La Inquisición: (intolerancia y derechos humanos) 8: 113-120.

Bethencourt, F. (1987), "Declínio e extinção do Santo Ofício", Revista de História Económica e Social 20: 77-85.

Bethencourt, F. (1994), História das Inquisiçôes: Portugal, Espanba e Itália, Círculo de Leitores, Lisboa.

Bethencourt, F. (2000), "A Inquisição", in A. C. GOUVEIA, J. F. MARQUES (coords.), História Religiosa de Portugal, vol. 2, Círculo de Leitores, Lisboa, 95-131.

Bethencourt, F. (2012), "A Inquisição revisitada", in Á. Garrido; L. F. Costa; L. M. Duarte (eds.), Estudos em homenagem a Joaquim Romero Magalhães: Economia, Instituiçôes e Império, Almedina, Coimbra, 145-156.

Braga, I. D. (2007), “À mesa com Grão Vasco. Para o estudo da alimentação no século XVI", Mathesis 16: 9-59.

Braga, I. D. (2009), "O auto da fé: uma festa apreciada e criticada", in Lisboa e a Festa: celebraçôes religiosas e civis na cidade medieval e moderna: colóquio de história e de história da arte: actas, Câmara Municipal, Lisboa, 87-103.

Buescu, A. I. (2011), "À mesa do rei. Cultura alimentar e consumo no século XVI", in A. I. Buescu, D. Felismino (eds.), A mesa dos reis de Portugal: ofícios, consumos, cerimónias e representações (séculos XIII-XVIII), Temas e Debates/Círculo de Leitores, Lisboa, 304-317.

Cardoso, A. B. (1997), "Vinho e fiscalidade na Época Moderna", Douro - Estudos \& Documentos 2.3: 71-83.

Costa, L. F. (2002), O transporte no Atlântico e a Companbia Geral do Comércio do Brasil (1580-1663), Comissão Nacional para as Comemorações dos Descobrimentos Portugueses, Lisboa.

Escudero Ríos, A.J. (1983), Autos de fe de la Inquisición de Granada, 1720-1731, [s.n.], Madrid.

Farinha, M. C. D. (1990), Os Arquivos da Inquisição, ANTT, Lisboa.

Felismino, D. (2011), "Dieta e gosto na mesa régia. Notas sobre dietética e alimentação 
na corte portuguesa (séculos XVII-XVIII)”, in A. I. Buescu, D. Felismino (eds.), A mesa dos reis de Portugal: ofícios, consumos, cerimónias e representaçóes (séculos XIIIXVIII), Temas e Debates/Círculo de Leitores, Lisboa, 351-380.

Fernández Carrasco, E. (2005), "Autos de Fe en Cuenca durante el reinado de Felipe IV (años: 1654 Y 1656)", Revista de La Inquisición: (intolerancia y derechos humanos) 11: 279-318.

García-Molina Riquelme, A. M. (1994), "El auto de fe de México de 1659: el saludador loco, López de Aponte”, Revista de La Inquisición: (intolerancia y derechos humanos) 3: 183-204.

Lahoz Finestres, J. M., Benedicto Gracia, E. (2011), "Una Relación de autos de fe celebrados en Aragón de 1485 a 1487", Revista de La Inquisición: (intolerancia y derechos humanos) 15: 13-26.

Lopes, B. (2014), "Uma primeira aproximação às contas da Inquisição portuguesa: o tribunal de Évora (1670-1770)", in Actas das XV Jornadas de Historia en Llerena: Inquisición, Sociedad Extremeña de Historia, Llerena, 77-94.

Lopes, B. (2016), “Os dinheiros da Inquisição portuguesa: o exemplo dos tribunais de Évora e Lisboa (1701-1755)”, Revista de História da Sociedade e da Cultura 16: 189-215.

López-Salazar Codes, A. I. (2011), Inquisición y política: el gobierno del Santo Oficio en el Portugal de los Austrias (1578-1653), Centro de Estudos de História Religiosa / Univ. Católica Portuguesa, Lisboa.

Maifreda, G. (2014), I denari dell'inquisitore: affari e giustizia di fede nell'Italia moderna, Einaudi, Torino.

Maqueda Abreu, C. (1986), “El auto de fe como manifestación del poder inquisitorial”, in J. A. Escudero López (ed.), Perfiles Jurídicos de La Inquisición Española, Universidad Complutense/Instituto de Historia de la Inquisición, Madrid, 407-414.

Marcocci, G., Paiva, J. P. (2013), História da Inquisição portuguesa (1536-1821), Esfera dos Livros, Lisboa.

Mattos, Y. (2014), A Inquisição Contestada: críticos e críticas ao Santo Ofício português (1605-1681), Mauad X, FAPERJ, Rio de Janeiro.

Megiani, A. P.T. (2011), "Os reis à mesa. Cerimónias e etiquetas: entre comidas públicas e merendas íntimas”, in A. I. Buescu, D. Felismino (eds.), A mesa dos reis de Portugal: ofícios, consumos, cerimónias e representações (séculos XIII-XVIII), Temas e Debates/Círculo de Leitores, Lisboa, 208-225.

Pereira, I. R. (1982), “O auto-da-fé de 1761”, Revista de História das Ideias 4: 367-376.

Saraiva, A. J. (1956), A Inquisição Portuguesa, Europa-América, Lisboa.

Saraiva, A. J. (1969), Inquisição e Cristãos-Novos, Estampa, Lisboa.

Saramago, A.(1997,3. a ed.), Doçaria conventual do Alentejo: as receitas e o seu enquadramento bistórico, Colares Editora, Sintra.

Silva, F. R. (2008), Quinhentos/Oitocentos (Ensaios de História), Faculdade de Letras da Universidade do Porto, Porto.

Sousa, D. F. F. (2011), A doçaria conventual de Coimbra: o segredo das madres conserveiras. Contributo para o seu estudo (séculos XVIII-XIX), Colares Editora, Sintra.

Veloso, C. (1992), A alimentação em Portugal no século XVIII nos relatos de viajantes estrangeiros, Livraria Minerva, Coimbra. 
(Página deixada propositadamente em branco) 